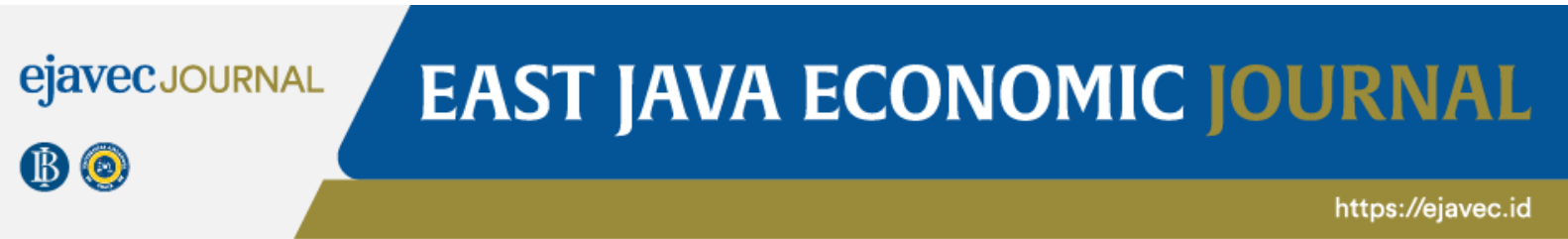

\title{
EFFICIENCY AND INCREASING PRODUCTIVITY OF THE MANUFAC- TURING INDUSTRY OF EAST JAVA PROVINCE
}

\author{
Lusi Sulistyaningsih*1 \\ Nita Ma'rufah' \\ Samsu Puji Estika ${ }^{3}$
}

1,2,3 Fakultas Ekonomi dan Bisnis, Universitas Airlangga, Indonesia

\begin{abstract}
This study aims to analyze technical efficiency and to find out the main contributors to the productivity of the manufacturing industry in East Java, which increased in 2007-2015. On the other hand, this research also aims to determine the direction of the efficiency of the manufacturing industry sub-sector and the factors that influence the level of efficiency of the manufacturing industry. Th level of efficiency that approaches the frontier signifies convergence, while divergence indicates that the level of efficiency that has not approached the frontier. There are 24 manufacturing industry sectors that were observed in this study. To calculate the value of technical efficiency, this study uses Data Envelopment Analysis (DEA) with a bootstrapping approach with 2000 times the number of iterations. While the calculation of productivity changes in this study uses the Malmquist Index. Conditional beta convergence analysis ( 6$)$, sigma convergence $(\sigma)$, gamma convergence $(\gamma)$, and stochastic convergence is used to analyze efficiency convergence. The results of the score of technical efficiency analysis show that the manufacturing industry in East Java is still in an inefficient condition with the electrical equipment industry being the highest efficiency score sector, while the furniture ind ustry is the most inefficient sector. Technological progress at 54 percent each year is a major contributor to the increase in manufacturing industry productivity by 55 percent during 2007-2015. On the other hand, the results of testing four convergence models show different results, sigma, gamma, and stochastic convergence indicating the convergence of manufacturing industry efficiency, while conditional beta convergence testing shows an indication of the divergence in manufacturing industry efficiency. The GMM estimation results show that factors that significantly affect the efficiency of manufacturing industries are energy intensity, capital-labor ratio, capital intensity, and industrial share.
\end{abstract}

Keywords: Technical Efficiency, Productivity, Convergence, Divergence, Manufacturing Industry

\begin{abstract}
ABSTRAK
Penelitian ini bertujuan untuk menganalisis efisiensi teknis serta untuk mengetahui kontributor utama penyumbang produktivitas industri manufaktur di Jawa Timur yang semakin meningkat tahun 2007-2015. Di sisi lain penelitian ini juga bertujuan untuk mengetahui arah efisiensi sub-sektor industri manufaktur. Tingkat efisiensi yang mendekati frontier menandakan terjadinya konvergensi, sedangkan divergen menandakan bahwa tingkat efisiensi yang belum mendekati frontier. Terdapat 24 sektor industri manufaktur yang diobservasi pada penelitian ini. Untuk menghitung nilai efisiensi teknis, penelitian ini menggunakan Data Envelopment Analysis (DEA) dengan pendekatan bootstrapping dengan 2000 kali jumlah iterasi. Sementara itu perhitungan perubahan produktivitas pada penelitian ini menggunakan Malmquist Index. Analisis konvergensi beta (B) kondisional, konvergensi sigma $(\sigma)$, konvergensi gamma $(\mathrm{v})$, dan konvergensi stokastik digunakan untuk menganalisis konvergensi efisiensi. Hasil skor analisis efisiensi teknis menunjukkan bahwa industri manufaktur di Jawa Timur masih berada pada kondisi yang tidak efisien dengan industri peralatan listrik menjadi sektor yang paling tinggi skor efisiensinya, se-
\end{abstract}

East Java Economic Journal, p-ISSN: 2597-8780, DOI: 10.53572/ejavec.v3i1.24, Open access under a Creative Commons Attribution- 4.0

*Korespondensi: Lusi Sulistyaningsih

E-mail: lusisulistya@gmail.com 
dangkan industri furnitur menjadi sektor yang paling tidak efisien. Technological progress sebesar 54 persen tiap tahun menjadi kontributor utama dalam peningkatan produktivitas industri manufaktur sebesar 55 persen sepanjang 2007-2015. Di sisi lain hasil pengujian empat model konvergensi menunjukkan hasil yang berbeda, yaitu konvergensi beta dan konvergensi stokastik yang mengindikasikan adanya kecenderungan divergensi efisiensi industri manufaktur. Pengujian konvergensi sigma dan konvergensi gamma menunjukkan adanya indikasi konvergensi efisiensi industri manufaktur.

Kata Kunci: Efisiensi Teknis, Produktivitas, Konvergensi, Divergen, Industri Manufaktur JEL: D24, L60

\section{Pendahuluan}

Negara Sedang Berkembang (NSB) menjadikan pembangunan sektor industri manufaktur sebagai prioritas utama dalam rencana pembangunan. Sektor industri manufaktur dianggap sebagai sektor yang mendorong perkembangan sektor lainnya, seperti jasa, perdagangan dan pertanian. Seiring dengan berjalannya waktu, sektor pertanian justru kurang mendapat perhatian yang mendalam karena industri manufaktur mulai diunggulkan. Sektor industri manufaktur telah mengalami perkembangan secara bertahap dan berkala pada perekonomian Indonesia. Memberikan kontribusi yang besar terhadap Produk Domestik Bruto (PDB), memberikan peningkatan pendapatan masyarakat, dan sektor manufaktur juga berperan dalam peningkatan penyerapan tenaga kerja.

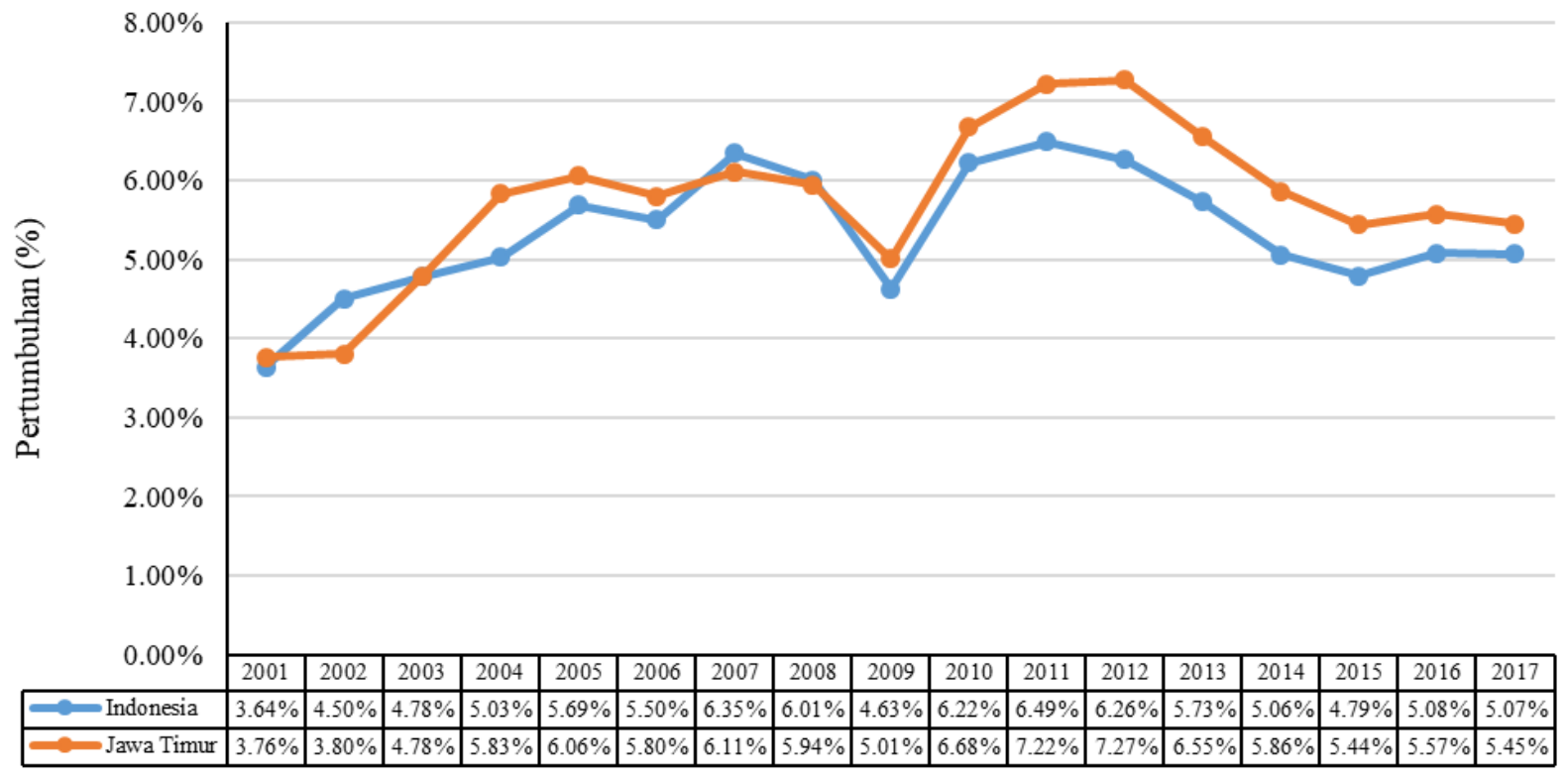

Sumber: BPS Provinsi Jawa Timur (2018)

\section{Gambar 1: Pertumbuhan Ekonomi Indonesia dan Provinsi Jawa Timur 2001-2017}

Jawa Timur merupakan salah satu provinsi dengan peran yang besar terhadap pertumbuhan ekonomi nasional. Sejak tahun 2009 hingga 2015, pertumbuhan ekonomi Jawa Timur selalu berada di atas pertumbuhan ekonomi nasional. Pada 2012 bahkan selisih pertumbuhan ekonomi Jawa Timur dengan pertumbuhan ekonomi Indonesia yakni 1,01\% (selisih tertinggi dalam perbandingan pertumbuhan ekonomi Jawa Timur dan Indonesia). Pertumbuhan Jawa Timur apabila dirata-rata yakni sebesar 5,71 persen sedangkan rata-rata pertumbuhan ekonomi Indonesia sebesar 5,34 persen. Kondisi ini menunjukkan posisi ekonomi Jawa Timur yang kuat dan menciptakan peningkatan daya beli masyarakat yang disebabkan kenaikan pendapatan dan penurunan harga barang secara umum. 
Pertumbuhan ekonomi Jawa Timur yang selalu berada di atas pertumbuhan ekonomi nasional tidak terlepas dari sektor unggulan yang mendorong pembangunan ekonomi di Jawa Timur. Industri pengolahan (manufaktur) merupakan sektor yang memiliki kontribusi terbesar pada perekonomian Jawa Timur yaitu 29,08 persen atau setara dengan Rp434.130,8 miliar. Sektor unggulan kedua yang menopang perekonomian Jawa Timur adalah perdagangan besar dan eceran dengan kontribusi 18,21 persen dari PDRB Jawa Timur pada 2017 atau setara dengan Rp273.213,4 miliar. Sektor lain yang menjadi penopang ekonomi Jawa Timur adalah pertanian, kehutanan, dan perikanan dengan kontribusi sebesar 12,82 persen atau setara dengan Rp167.197,7 miliar.

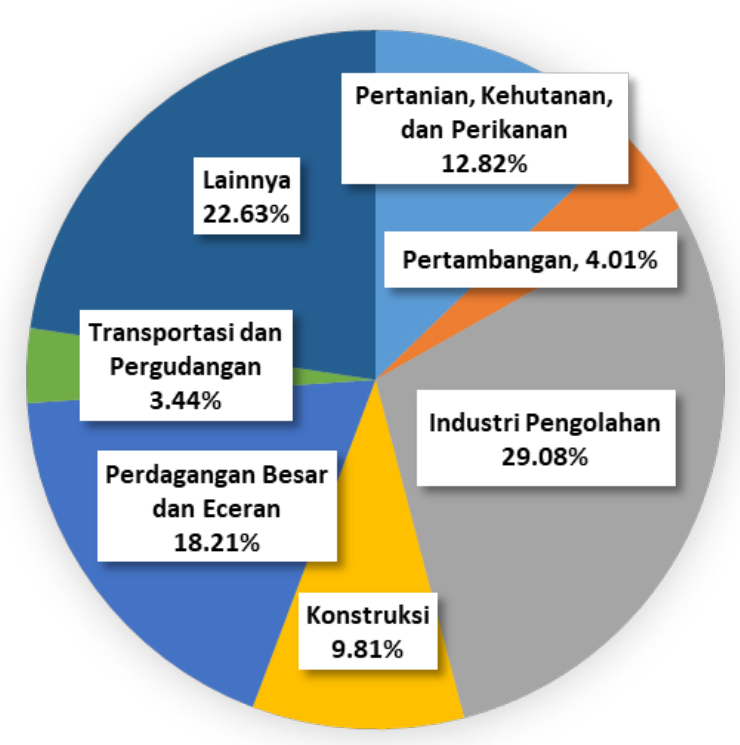

Sumber: BPS Provinsi Jawa Timur (2018)

\section{Gambar 2: PDRB Sektoral Provinsi Jawa Timur pada 2017}

Parsons (2001) dalam Wajdi (2010) mengatakan bahwa berbagai macam alternatif dapat digunakan untuk menilai kinerja suatu industri. Pengukuran kinerja tersebut dapat dikelompokkan menjadi ukuran keuangan dan ukuran non-keuangan atau operasional perusahaan. Penilaian kinerja industri manufaktur dalam penelitian ini diukur menggunakan nilai efisiensi dan produktivitas (operasional industri). Farrell (1957) menyebutkan bahwa penilaian produktivitas dan efisiensi untuk mengukur kemampuan sebuah perusahaan dalam memproduksi suatu output secara maksimal dengan nilai input yang telah ditetapkan atau memproduksi suatu output tertentu dengan input yang minimal adalah penting dilakukan untuk mengonstruksi strategi improvement. Untuk mendapatkan nilai efisiensi setiap perusahaan, metode Data Envelopment Analysis (DEA) digunakan dalam penelitian ini sebab sifatnya yang multi-output dan multi-input dan dapat digunakan pada data input dan output yang berbeda unit sehingga memudahkan proses analisis bagi peneliti (Flokou dkk, 2017). Di sisi lain penilaian produktivitas juga diterapkan dalam penelitian ini. Definisi produktivitas menurut Coelli dkk (2005) adalah ukuran rasio dari output yang dapat dihasilkan suatu perusahaan dengan seluruh input sumberdaya yang digunakan. Indeks Total Factor Productivity Change (TFPC) yang menjadi tolak ukur untuk pengukuran produktivitas melibatkan semua faktor produksi yang terdiri dari komponen Technical Efficiency Change (TEC), Scale Efficiency Change (SEC), dan Technological Change (TC). Oleh karena itu tujuan dari penulisan ini yaitu: menghitung tingkat efisiensi pada industri manufaktur di Provinsi Jawa Timur, menganalisis tingkat 
konvergensi efisiensi pada sektor industri manufaktur di Provinsi Jawa Timur, dan menguji pengaruh intensitas energi, rasio modal-tenaga kerja, intensitas modal, dan share industri berpengaruh terhadap efisiensi sektor industri manufaktur di Provinsi Jawa Timur.

\section{Telaah Literatur}

\section{Teori Produksi}

Produksi merupakan suatu proses pengubahan bentuk input menjadi output maupun segala usaha yang dilakukan untuk menambah nilai suatu barang. Nicholson dan Synder (2010) kemudian mengatakan bahwa model fungsi produksi kemudian dibentuk untuk mengonstruksikan output suatu produksi dengan berbagai kombinasi input yang digunakan. Persamaan merupakan bentuk dari fungsi produksi di mana mendenotasikan kombinasi input yang digunakan (misalnya tenaga kerja, mesin, dan bahan baku) untuk menghasilkan sejumlah output. Kemungkinan dari teknologi yang digunakan perusahaan juga dapat diakomodir dalam fungsi di atas. Fungsi produksi kemudian umumnya menggunakan dua input untuk suatu proses produksi agar dapat dipahami dengan gambar dua dimensi. Oleh sebab itu pada umumnya diasumsikan bahwa perusahaan menggunakan dua input (capital dan labor) dalam proses produksinya sehingga fungsi produksinya menjadi

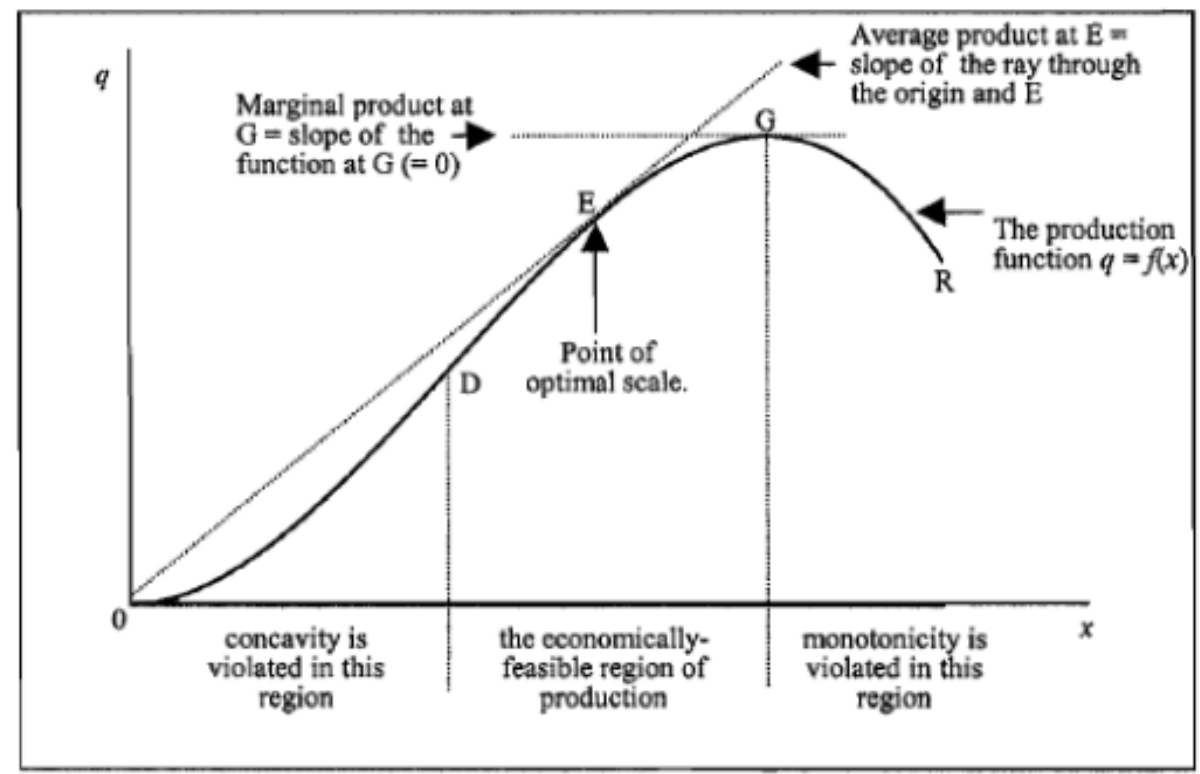

Sumber: Coelli, dkk (2005:14)

\section{Gambar 3: Fungsi Produksi Single-Input}

Gambar 3 memberikan ilustrasi fungsi produksi dengan satu input dan satu output. Chambers (1988) dalam Coelli dkk (2005:12) mengatakan bahwa terdapat 4 sifat fungsi produksi yaitu: (a) non negativity yang berarti bahwa nilai dari fungsi produksi adalah dapat ditentukan (finite), tidak negatif, dan riil; (b) weak essentiality bahwa menggunakan setidaknya satu input untuk menghasilkan output yang bernilai positif; (c) non decreasing in $\mathrm{x}$ atau bersifat monotonic yang berarti bahwa penambahan suatu input tidak akan mengurangi output dengan asumsi bahwa $x_{0} \geq x_{1}$ sehingga $f\left(x_{0}\right) \geq f\left(x_{1}\right)$; dan (d) concave in $\mathrm{x}$ atau law of diminishing return terjadi karena adanya berbagai kombinasi linear dari vektor $\mathrm{x} 0$ dan $\mathrm{x} 1$ yang berproduksi menghasilkan suatu output yang lebih dari atau sama dengan $f\left(x_{0}\right)$ dan $f\left(x_{1}\right)$.

Fungsi produksi KLE merupakan perluasan fungsi produksi KL yang hanya menggunakan dua input dalam produksinya. Fungsi produksi KLE menggunakan tiga input yaitu modal 
(K), tenaga kerja (L) dan Energi (E). Fungsi produksi dengan tiga input dapat dituliskan sebagai berikut:

$$
Q=f(K, L, E)
$$

Bentuk lain dari fungsi produksi dengan tiga input menggunakan fungsi produksi Cobb-Douglas dapat dituliskan sebagai berikut:

$$
Q=\alpha_{0} L^{\alpha_{1}} K^{\alpha_{2}} E^{\alpha_{3}}
$$

Input energi merupakan salah satu faktor produksi yang berperan penting dalam berbagai industri manufaktur dan merupakan sumber yang penting pada pertumbuhan ekonomi serta efektivitas produksi (Khayyat, 2015:4). Oleh karena itu, input energi mulai banyak digunakan sebagai faktor produksi dalam analisis di industri maupun sektor lainnya.

\section{Konsep Produktivitas dan Efisiensi}

Suatu proses produksi dikatakan memiliki produktivitas tinggi apabila rasio output terhadap input nya memiliki nilai yang tinggi, sehingga produktivitas pada suatu industri dapat diukur dari rasio tingkat output terhadap unit penggunaan input produksi. Tangen (2002) juga menambahkan bahwa produktivitas erat kaitannya dengan penggunaan dan ketersediaan sumberdaya. Sehingga dapat dikatakan bahwa produktivitas akan berkurang jika sumberdaya perusahaan tidak digunakan dengan benar atau jika terjadi kekurangan pada sumberdaya perusahaan. Untuk melakukan analisis suatu industri yang simultan diperlukan perhitungan total faktor produktivitas yang melebihi perhitungan produktivitas parsial agar mendapatkan hasil yang tepat dan akurat. Dalam perhitungan total produktivitas dibutuhkan keterkaitan antara suatu tingkat output dengan beberapa jenis kombinasi input, sedangkan perhitungan produktivitas parsial hanya mengaitkan suatu tingkat output dengan satu jenis input saja.

Greene (1997) dalam Porcelli (2009) menjelaskan bahwa suatu proses produksi dapat dikatakan efisien secara teknis apabila telah mampu berproduksi menghasilkan output yang maksimal menggunakan unit input tertentu atau mampu menghasilkan suatu output tertentu dengan unit input yang minimum. Skor efisiensi adalah 1 (100 persen) apabila mampu beroperasi pada production frontier (kondisi yang efisien), sedangkan skor kurang dari 1 menggambarkan perusahaan yang beroperasi tidak efisien (inefisien). Berbagai metode dapat dilakukan untuk melakukan penilaian efisiensi baik melalui pendekatan parametrik seperti Stochastic Frontier Approach (SFA), Thick Frontier Approach (TFA), dan Distribution Free Approach (DFA), maupun pendekatan non-parametrik yang meliputi Data Envelopment Analysis (DEA) dan Free Disposal Hull (FDH). Pendekatan parametrik digunakan untuk mengukur efisiensi ekonomi yang lebih luas pengertiannya dari efisiensi teknis sehingga memerlukan data efisiensi teknis dan efisiensi alokasi serta data harga. Pendekatan non-parametrik dirasa sesuai dengan penelitian ini sebab dapat menemukan nilai efisiensi teknis dari data input dan output (Vincova dkk, 2005). Lubis (2014) mengatakan bahwa metode FDH menghasilkan nilai estimasi yang lebih besar dari DEA, hal tersebut karena metode FDH hanya memasukkan nilai DEA yang paling efisien serta terbebas dari poin disposal hull. Oleh karena itu penelitian ini menggunakan metode DEA sehingga FDH tidak dibahas lagi.

DEA melibatkan penggunaan metode Linear Programming untuk membangun sebuah frontier non-parametrik pada data serta memiliki asumsi bahwa tidak terdapat random error (Vincova dkk, 2005). Istilah DEA mulai diperkenalkan oleh Charnes pada tahun 1978 yang didasarkan pada penelitian Farrell (1957). Keuntungan metode ini adalah sifatnya yang 
multi-output dan multi-input, sehingga memudahkan proses analisis bagi peneliti (Flokou dkk, 2017). Diskaya dkk (2011) mengatakan bahwa terdapat 3 metode yang dapat dilakukan dalam analisis menggunakan pendekatan DEA, yaitu metode CCR (Charnes-Cooper-Rhodes), metode BCC (Banker-Charnes-Cooper), dan metode SBM (Slacks-Based Measure of efficiency). Metode CCR yang berkembang pada tahun 1978 didasarkan pada asumsi fixed return to scale atau Constant Return to Scale (CRS) yang berarti bahwa rasio penambahan output adalah sama dengan rasio dari penambahan inputnya. Model ini juga berasumsi bahwa suatu perusahaan atau unit pengambil keputusan (Decision Making Unit atau DMU) beroperasi pada skala yang optimal. Di sisi lain, metode BCC yang merupakan pengembangan dari metode CCR pada tahun 1984 memiliki asumsi bahwa DMU tidak atau belum beroperasi pada skala yang optimal, sehingga rasio penambahan output dapat lebih besar (Increasing Return to Scale atau IRS) atau bahkan lebih kecil (Decreasing Return to Scale atau DRS) dari rasio penambahan inputnya (Rusydiana, 2013).

Gambar 4 menggambarkan production frontier (tingkat produksi yang efisien) perusahaan. Di bawah asumsi CRS, perusahaan $C^{\prime}$ dan $D$ bersifat efisien secara teknis. Di sisi lain, perusahaan $B, C, D, E$, dan $F$ juga efisien secara teknis di bawah asumsi VRS, sedangkan perusahaan $A$ berproduksi secara inefisien dan berada di luar garis frontier VRS. Perusahaan A dapat menjadi efisien seperti perusahaan $E$ apabila dapat meningkatkan outputnya dari $\mathrm{q}_{1}$ menuju $\mathrm{q}_{2}$ dengan tingkat input $\mathrm{x}_{2}$ yang tetap (output oriented). Alternatif lain tersedia apabila perusahaan A memutuskan beroperasi secara efisien seperti perusahaan $C$ sehingga harus melakukan pengurangan input yang digunakan pada proses produksinya dari $\mathrm{x}_{2}$ menuju $\mathrm{x}_{1}$ agar output yang diproduksi tetap sebesar $\mathrm{q}_{1}$ (input oriented).

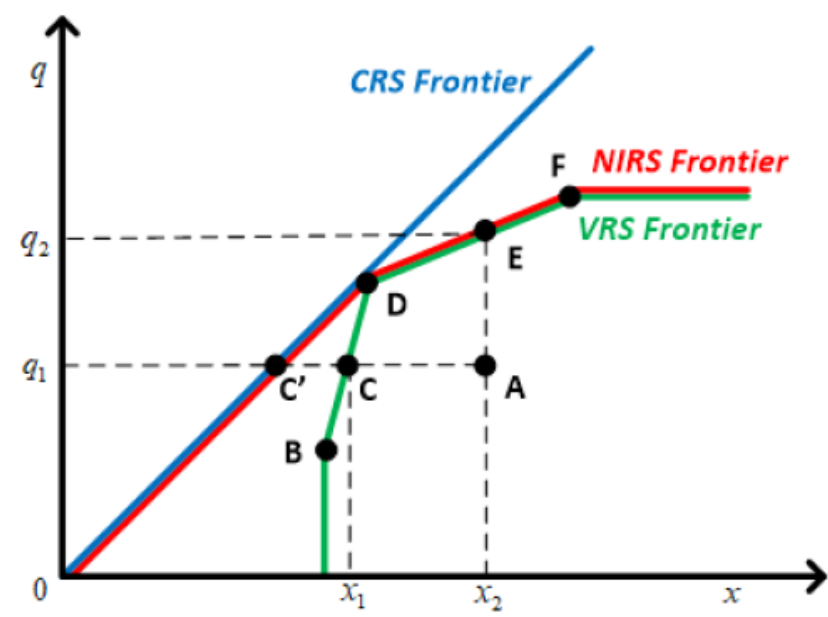

Sumber: Coelli, dkk (2005:174)

\section{Gambar 4: Production Frontier, Efisiensi Teknis, dan Efisiensi Skala}

Gambar 4 tersebut juga mengilustrasikan penghitungan efisiensi skala menggunakan asumsi single input dan single output. Di bawah asumsi CRS dengan berorientasi pada input, terjadi inefisiensi pada perusahaan $C$ yaitu pada sepanjang titik $C$ hingga $C^{\prime}$. Di sisi lain, apabila di bawah asumsi VRS, perusahaan $\mathrm{C}$ telah efisien. Oleh karena itu dapat disimpulkan bahwa adanya selisih pengukuran efisiensi teknis (di bawah asumsi CRS dan VRS) disebabkan oleh adanya inefisiensi skala yaitu pada sepanjang titik $C$ hingga titik $C^{\prime}$. Berdasarkan ilustrasi tersebut, pengukuran efisiensi skala dapat dilakukan dengan formulasi berikut: 


$$
\text { Scale Efficiency }=\frac{q_{1} C^{\prime}}{q_{1} C}=\frac{\text { Technical Efficiency } C R S}{\text { Technical Efficiency } V R S}
$$

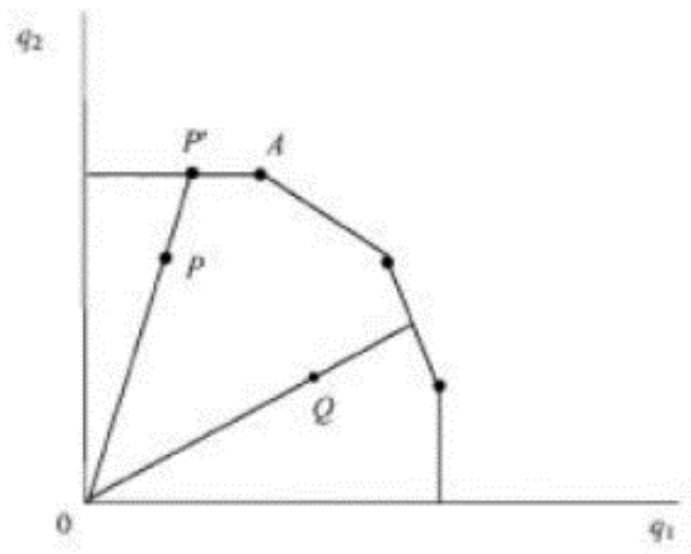

Sumber: Coelli, dkk (2005:181)

\section{Gambar 5: DEA Output Oriented}

Penelitian ini berorientasi pada output dengan asumsi bahwa industri manufaktur beroperasi pada aktivitas produksi yang memaksimalkan output dengan input yang dianggap konstan. Gambar 5 mengilustrasikan metode DEA dengan asumsi output oriented dan menghasilkan 2 output dengan input yang tetap. Sumbu horizontal adalah $\mathrm{q}_{1}$ yang menunjukkan output pertama dan sumbu vertikal adalah $\mathrm{q}_{2}$ yang menunjukkan output kedua. Pada kasus Gambar 5 di atas, titik $P$ yang diproyeksikan akan berada di titik $P^{\prime}$ dan beroperasi pada garis frontier perusahaan, namun bukan pada kondisi yang efisien. Hal tersebut karena produksi $q_{1}$ seharusnya dapat ditingkatkan dari titik $\mathrm{P}^{\prime}$ menuju titik $A$ tanpa menambah input sama sekali (penggunaan input tetap) sehingga produksi berada pada ouput $\mathrm{q}_{1}$ dan $\mathrm{q}_{2}$ yang optimal. Oleh karena itu, dapat disimpulkan bahwa pada ilustrasi tersebut terdapat slack sebesar AP' pada output $q_{1}$.

\section{Konsep Perubahan Produktivitas dan Perubahan Efisiensi}

Pengukuran perubahan produktivitas atau Total Factor Productivity Change (TFPC) dengan menggunakan keseluruhan output hasil produksi dengan keseluruhan input produksi pada keseluruhan periode dirasa lebih efektif dari pada melakukan pengukuran yang hanya didasarkan pada satu periode variabel input dan satu periode variabel output saja. Flokou (2017) menjelaskan bahwa pengukuran perubahan produktivitas serta dekomposisinya (technical efficiency change, scale efficiency change, dan technological change) dapat menggunakan Malmquist Index yang diperkenalkan oleh Caves pada tahun 1982. Menurut Coelli dkk (2005:85), penghitungan Malmquist Index didasarkan pada publikasi Fare dkk pada tahun 1994 yang merupakan pendekatan non-parametrik sehingga dapat mengakomodir penelitian yang multi-input dan multi-output tanpa menentukan fungsi tujuan terlebih dahulu.

Flokou dkk (2017) mengatakan bahwa perubahan efisiensi teknis mengukur tingkat perubahan efisiensi relatif pada periode $s$ (tahun pertama) dengan efisiensi relatif pada periode $t$ (tahun kedua). Oleh karena itu Technical Efficiency Change (TEC) ini biasa disebut dengan catching-up effect yang mencerminkan komponen perubahan efisiensi dalam perubahan produktivitas. Komponen TEC dapat didekomposisikan menjadi Pure Efficiency Change (PEC) dan Scale Efficiency Change (SEC) dengan menggunakan asumsi VRS pada kedua periode waktunya (TS VRS dan Tt VRS). Nilai TEC lebih dari 1 (100 persen) jika perusahaan mengalami 
peningkatan efisiensi, sedangkan nilai TEC yang kurang dari 1 (100) persen menandakan perusahaan mengalami peurunan efisiensi. Scale Efficiency Change (SEC) merupakan rasio perbandingan dari scale efficiency pada periode $\boldsymbol{t}$ (tahun kedua) dengan scale efficiency pada periode $\boldsymbol{s}$ (tahun pertama). Balk (2001) mengatakan bahwa SEC tidak bergantung pada perubahan teknis atau TEC. Apabila SEC bernilai lebih dari 1 (100 persen) maka perusahaan beroperasi mendekati garis frontier (berproduksi secara optimal), dan sebaliknya nilai kurang dari 1 mengindikasikan bahwa perusahaan beroperasi menjauhi garis frontier (tidak optimal).

Kemajuan teknologi dapat menyebabkan fungsi produksi berubah dari waktu ke waktu (year $\boldsymbol{s}$ ke year $\boldsymbol{t}$ ) seperti yang diilustrasikan pada Gambar 6. Paredes (2016) menyebutkan bahwa kemajuan teknologi memungkinkan perusahaan berproduksi menghasilkan output lebih banyak dengan kombinasi input tertentu yang tetap atau dengan memproduksi output di tingkat yang sama namun dengan menggunakan kombinasi input yang lebih sedikit. Oleh karena itu kemajuan teknologi sering disebut dengan frontier shift change, hal ini karena perusahaan beroperasi pada kondisi yang optimal dengan kondisi optimal (frontier) yang semakin meningkat (Flokou, 2017).

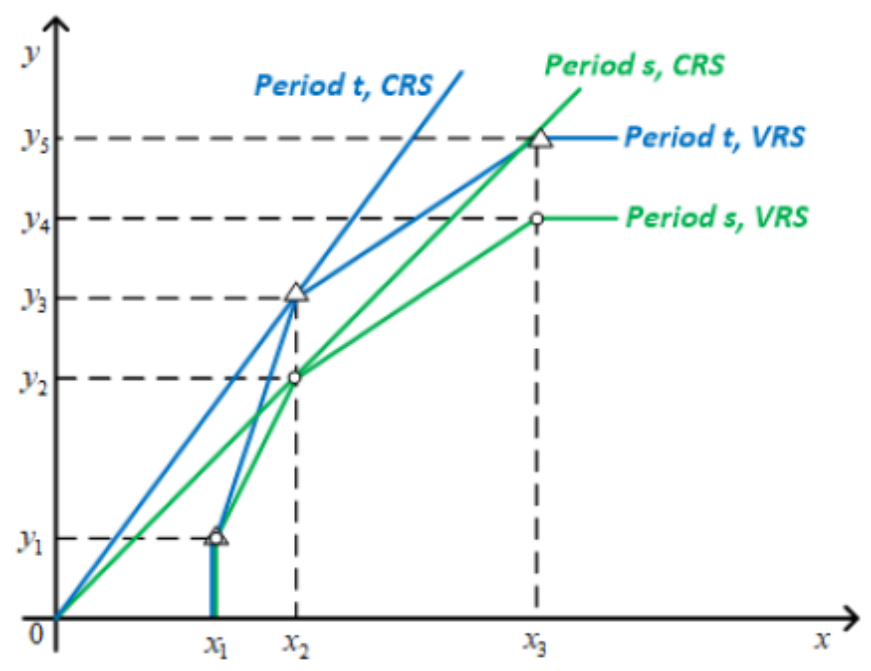

Sumber: Coelli, dkk (2005:174)

\section{Gambar 6: DEA Malmquist, Output Oriented}

\section{Konsep Konvergensi}

Konsep konvergensi berasal dari teori pertumbuhan ekonomi neoklasik (Solow) yang menyatakan bahwa perekonomian dengan PDB per kapita awal yang lebih rendah akan memiliki pertumbuhan ekonomi yang lebih tinggi, sehingga pada satu waktu akan mampu mengejar perekonomian dengan PDB per kapita yang lebih tinggi (Hao et al., 2015:2618). Menurut Valdés (2003:62) setiap perekonomian memiliki kondisi steady state masing-masing yang merupakan plafon atau standar pertumbuhan yang memungkinkan untuk terjadinya pendapatan per kapita yang berkelanjutan. Pada Gambar 7 dapat dilihat bagaimana terjadinya proses catching up effect hingga mencapai kondisi steady state. Jalur atau path D merupakan jalur pertumbuhan ekonomi yang dimiliki oleh negara atau wilayah yang maju, sedangkan jalur $\mathrm{C}$ merupakan jalur yang dimiliki oleh negara atau wilayah yang sedang berkembang. Jalur pertumbuhan ekonomi yang dimiliki oleh wilayah yang maju sudah tidak bisa meningkat lagi karena sudah mendekati jalur steady state. Pada saat itu, jalur pertumbuhan ekonomi yang dimiliki oleh negara sedang berkembang terus mengalami peningkatan dengan cepat, sehingga akan mampu menyamai kondisi pertumbuhan ekonomi wilayah maju pada kondisi steady state. 


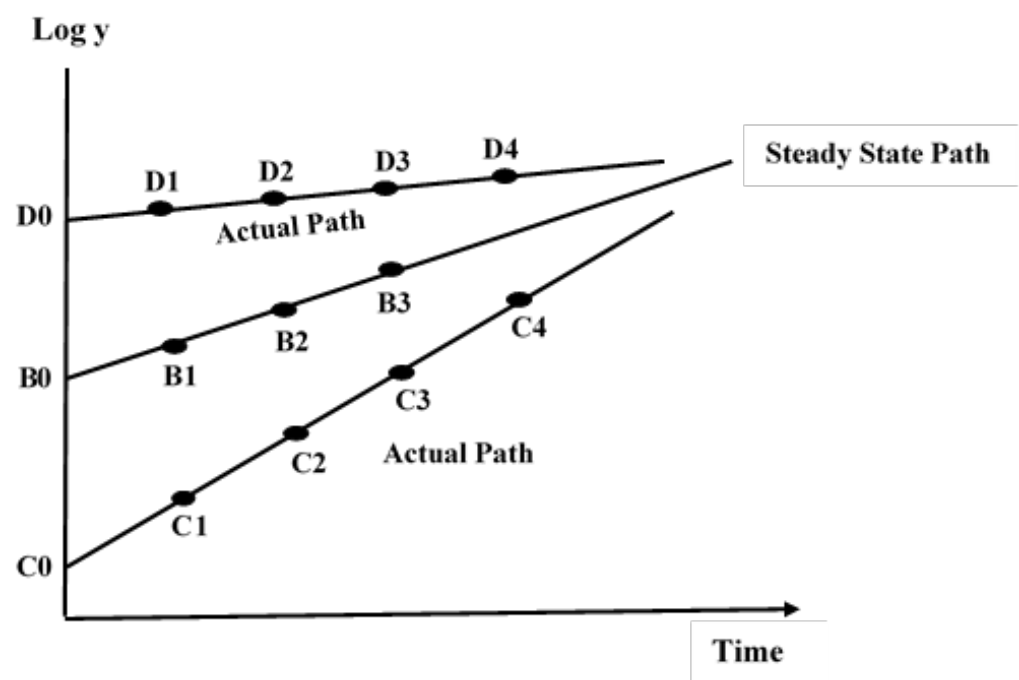

Sumber: Valdés (2003:63)

\section{Gambar 7: Proses Mencapai Steady State Path}

Konvergensi merupakan proses menuju titik pertumbuhan ekonomi yang sama atau memusat. Secara umum konvergensi bisa dipahami sebagai proses pengurangan kesenjangan pertumbuhan atau terjadinya penurunan perbedaan pendapatan per kapita antara wilayah dengan perekonoman lebih miskin dan wilayah dengan perekonomian lebih kaya yang disebabkan oleh pertumbuhan ekonomi yang sangat cepat (Abramovitz, 1986:386). Barro dan Martin (1996:1020) mengemukakan dua hipotesis mengenai konsep konvergensi yaitu konvergensi beta $(\beta)$ dan konvergensi sigma $(\sigma)$. Konvergensi beta absolut menyatakan bahwa wilayah dengan perekonomian yang lebih miskin cenderung memiliki pertumbuhan ekonomi yang lebih tinggi dibandingan dengan wilayah dengan perekonomian yang lebih kaya.

Dua hipotesis konvergensi yang dikemukakan oleh Barro dan Martin (1996:1020) memiliki keterkaitan satu sama lain, sehingga menghasilkan kesimpulan bahwa wilayah dengan pertumbuhan ekonomi yang lebih rendah suatu saat akan mampu mengejar (catch up) wilayah dengan pertumbuhan ekonomi yang lebih tinggi. Hal ini disebabkan karena wilayah dengan pertumbuhan ekonomi yang rendah tumbuh lebih cepat, selain itu wilayah dengan pertumbuhan yang lebih tinggi sudah berada pada kondisi steady-state, sehingga memungkinkan kedua wilayah tersebut akan setara dalam hal pertumbuhan ekonomi. Asumsi yang berlaku untuk teori konvergensi ini yaitu preferensi dan tingkat teknologi yang digunakan oleh kedua wilayah sama dan berlaku dari satu perekonomian ke perekonomian lainnya, meskipun dalam kondisi nyata teknologi yang dimiliki negara maju cenderung lebih baik dibanding negara sedang berkembang.

Konvergensi memiliki konsep yang berbeda dalam pengukurannya. Berikut ini adalah jenis-jenis konvergensi berdasarkan pengukurannya:

\section{a. Konvergensi Beta Kondisional ( $\beta$-Convergence)}

Konvergensi Beta digunakan untuk mengetahui arah konvergensi dan juga mengetahui pengaruh faktor-faktor yang diperkirakan dapat menentukan tingkat intensitas energi. Barro dan Martin (1996:1025) menyatakan bahwa pertumbuhan ekonomi negara berkembang akan lebih pesat dibandingkan dengan negara maju atau dikenal dengan hipotesis konvergensi beta. Jenis konvegensi ini dibagi menjadi dua yaitu unconditional convergence (konvergensi absolut) dan conditional convergence (konvergensi kondisional). Konvergensi absolut hanya 
memperhitungkan satu faktor penentu konsumsi energi per kapita, yaitu tingkat konsumsi energi per kapita periode sebelumnya (lag), sedangkan konvergensi beta kondisional mempertimbangkan beberapa faktor yang mungkin mempengaruhi tingkat konvergensi. Faktor tersebut disesuaikan dengan karakteristik masing-masing objek. Konvergensi beta terjadi ketika koefisien variabel lag bernilai negatif, sedangkan jika bernilai positif maka terjadi divergensi beta.

\section{b. Konvergensi Sigma ( $\sigma$-Convergence)}

Konvergensi sigma $(\sigma)$ merupakan konsep konvergensi yang pengukurannya menggunakan dispersi yang terjadi antar perekonomian, dalam penelitian ini adalah intensitas energi antar sub-sektor industri manufaktur. Konvergensi sigma $(\sigma)$ berfokus pada ketimpangan atau gap antara perekonomian wilayah yang maju dan wilayah berkembang yang diukur dengan standar deviasi. Menurut Barro dan Martin (1996:1025) konvergensi sigma memungkinkan adanya catch-up effect oleh wilayah berkembang karena gap pertumbuhan antara wilayah maju dan wilayah berkembang cenderung mengalami penurunan. Konvergensi sigma terjadi ketika standar deviasi cenderung mengalami penurunan, sedangkan jika cenderung mengalami peningkatan maka terjadi divergensi sigma.

\section{c. Konvergensi Gamma ( $\gamma$-Convergence)}

Konvergensi Gamma $(\gamma)$ mengukur tingkat konvergensi pertumbuhan ekonomi suatu wilayah dengan melihat mobilitias intra-distribusional atau perpindahan peringkat. Konsep konvergensi gamma berfokus pada mobilitas peringkat masing-masing wilayah. Peringkat tersebut dihitung menggunakan indeks gamma. Nilai indeks gamma berkisar antara 0 hingga 1. Indeks 1 menunjukkan bahwa peringkat antar wilayah tidak mengalami perubahan, sedangkan indeks 0 menandakan terjadinya mobilitas peringkat yang tinggi antar wilayah. Konvergensi terjadi ketika indeks gamma mengalami penurunan atau mendekati 0 , sedangkan ketika indeks gamma mengalami kenaikan dan mendekati 1 maka terjadi divergensi gamma.

\section{d. Konvergensi Stokastik (Stochastic Convergence)}

Konvergensi stokastik menganalisis apakah guncangan pada variabel level relatif terhadap rata-rata sampel pada variabel bersifat sementara atau berlangsung terus-menerus (Liddle, 2012:590). Variasi antara konsumsi energi per kapita dan rata-rata konsumsi energi per kapita untuk semua negara bagian harus sesuai atau stasioner. Stasioner adalah suatu kondisi data time series yang jika rata-rata, varian, dan kovarian dari peubah-peubah tersebut seterusnya tidak berubah meskipun terdapat penambahan waktu. Konvergensi stokastik terjadi ketika data stationer, sedangkan divergensi stokastik terjadi ketika data tidak stasioner.

\section{Metode Penelitian}

\section{Jenis dan Sumber Data}

Tabel 1: Sumber Data

\begin{tabular}{lll}
\hline No. & \multicolumn{1}{c}{ Data } & \multicolumn{1}{c}{ Sumber Data } \\
\hline 1 & Survei Industri Besar-Sedang (IBS) Tahun 2007-2015 & Badan Pusat Statistik \\
\hline 2 & Indeks Harga Perdagangan Besar (IHPB) & Badan Pusat Statistik \\
\hline 3 & Indeks Harga Konsumen (IHK) & Badan Pusat Statistik \\
\hline 4 & Konversi Satuan Energi & Institut Pertanian Bogor (IPB) \\
\hline
\end{tabular}

Data yang digunakan dalam penelitian ini adalah data sekunder yang berupa data panel (pooled data) yaitu gabungan antara data time series antara tahun 2007 hingga 2015 dan data cross-section dari 24 industri manufaktur di Pulau Jawa. Data sekunder tersebut diper- 
oleh dari berbagai sumber seperti publikasi institusi, laporan tahunan, data statistik, dan berbagai sumber lainnya dari internet maupun buku (Lihat Tabel 1).

\section{Metode Analisis Data}

Penelitian ini menggunakan pendekatan statistik inferensial yang dilakukan dengan melakukan pengujian statistik atau uji hipotesis bedasarkan teori dan penelitian sebelumnya untuk mengetahui arah konvergensi efisiensi industri manufaktur dan mengetahui faktor yang mempengaruhi tingkat efisiensi itu sendiri. Pendekatan tersebut menggunakan metode regresi data panel dinamis. Di sisi lain, Data Envelopment Analysis (DEA) dan Malmquist Index juga digunakan untuk menghitung nilai efisiensi dan perubahan produktivitas setiap industri manufaktur di Jawa Timur. Perhitungan regresi panel dinamis dan perhitungan Malmquist Index menggunakan bantuan software STATA 13.0, sedangkan perhitungan DEA diolah menggunakan software MaxDEA.

Penelitian ini menggunakan beberapa teknik analisis, yaitu efisiensi dan produktivitas serta analisis data panel dinamis.

A. Model Analisis Malmquist Index

$$
\operatorname{TFPC}^{s, t}\left(x_{s}, x_{t}, q_{s}, q_{t}\right)=\frac{d_{0}^{t}\left(x_{t}, q_{t}\right)}{d_{0}^{s}\left(x_{s}, q_{s}\right)} \times \frac{S E_{0}^{t}\left(x_{t}, q\right)}{S E_{0}^{s}\left(x_{s}, q\right)} \times\left[\frac{d_{0}^{t}\left(x_{t}, q_{t}\right)}{d_{0}^{t}\left(x_{t}, q_{t}\right)} \times \frac{d_{0}^{s}\left(x_{s}, q_{s}\right)}{d_{0}^{s}\left(x_{s}, q_{s}\right)}\right]^{\frac{1}{2}}
$$

B. Model Analisis Konvergensi Beta $(\beta)$ Kondisional

$$
\ln V R S_{i t}=\beta_{0}+\beta_{1} \ln V R S_{i t-1}+\beta_{2} \ln I E_{i t}+\beta_{3} \ln C L_{i t}+\beta_{4} \ln I C_{i t}+\beta_{5} \ln S I_{i t}+\varepsilon_{i t}
$$

C. Model Analisis Konvergensi Sigma ( $\sigma$ )

$$
\sigma_{i t}=\sqrt{\frac{1}{n} \sum_{i=1}^{n}\left(\log V R S_{i t}-\log \overline{V R S_{i t}}\right)^{2}}
$$

D. Model Analisis Konvergensi Gamma $(\gamma)$

$$
\gamma=\frac{\operatorname{Variance}\left[R(E)_{i t}+R(E)_{i 0}\right]}{\text { Variance }\left[2 R(E)_{i 0}\right]}
$$

E. Model Analisis Konvergensi Stokastik

$$
V R S_{i t}=\varnothing V R S_{i t-1}+u_{i t}
$$

\section{Definisi Operasional Variabel}

Definisi operasional variabel yang digunakan dalam menghitung efisiensi serta produktivitas Industri Manufaktur yaitu sebagai berikut:

1. Variabel Output

a. Output industri manufaktur

Nilai yang dihasilkan masing-masing perusahaan melalui proses produksi industri manufaktur di Jawa Timur dalam satuan rupiah. Nilai output dikonstankan menggunakan Indeks Harga Perdagangan Besar (IHPB) tahun dasar 2010.

b. Value Added

$$
\text { Output }(Y)=\frac{\text { NilaiOutput }_{\text {firmi }}}{\text { IHPB }_{2010}}
$$

Nilai tambah yang merupakan pengurangan output terhadap input. 


$$
\text { Value Added }(V A)=\text { Nilai Output }- \text { Nilai Input }
$$

2. Variabel Input

a. Modal

Nilai modal tetap atau fixed capital dari masing-masing perusahaan untuk kegiatan produksi dalam industri manufaktur di Jawa Timur yang terdiri atas tanah, gedung, kendaraan, mesin dan perlengkapan, serta lainnya dalam satuan rupiah. Nilai modal tetap dikonstankan menggunakan Indeks Harga Perdagangan Besar (IHPB) tahun dasar 2010.

$$
\operatorname{Modal}(K)=\frac{\text { Nilai Total Modal Tetap }}{\text { firm } i}
$$

b. Tenaga Kerja

Jumlah pekerja baik pekerja dibayar laki-laki dan perempuan maupun pekerja yang tidak dibayar laki-laki dan perempuan pada industri manufaktur dalam satuan orang.

c. Energi

Jumlah energi yang digunakan dalam proses produksi oleh masing-masing perusahaan melalui proses produksi pada industri manufaktur di Jawa Timur dalam satuan Setara Barel Minyak (SBM).

d. Bahan Baku

Nilai dari semua jenis bahan baku dan bahan penolong yang digunakan dalam proses produksi dan tidak termasuk: pembungkus, pengepak, pengikat barang jadi, bahan bakar yang dipakai habis, perabot atau peralatan.

e. Upah

Balas jasa baik berupa uang atau barang yang diberikan langsung kepada buruh untuk suatu pekerjaan/jasa yang telah dilakukan. Upah yang disajikan di sini adalah upah yang diberikan dalam bentuk uang per orang dalam satu hari. Upah buruh didalam publikasi ini tidak dikaitkan dengan kriteria umur, tingkat pendidikan dan lain sebagainya.

Definisi operasional variabel yang digunakan untuk menganalisis konvergensi serta faktor-faktor yang mempengaruhi efisiensi industri yaitu sebagai berikut:

1. Intensitas energi

Intensitas energi adalah rasio antara konsumsi energi dalam Satuan Barel Minyak (SBM) dengan PDB (Rupiah) per sektor industri manufaktur. Nilai intensitas energi dapat dihitung dengan persamaan berikut:

$$
\text { Intensitas energi } i_{i t}=\frac{\text { Konsumsi Energi } i_{i t}}{P D B_{i t}}
$$

2. Capital-Labor Ratio (Rasio Modal-Tenaga Kerja)

Capilat-labor rastio adalah rasio antara modal (Rupiah) dengan tenaga kerja (Rupiah) yang digunakan dalam proses produksi masing-masing industri manufaktur.

3. Intensitas Modal

Intensitas modal adalah rasio antara modal (Rupiah) dengan PDB (Rupiah) per sektor industri manufaktur.

4. Share Industri

Share industri adalah peranan masing-masing industri manuaktur terhadap Output industri manufaktur secara keseluruhan.

\section{Hasil Dan Pembahasan}

Hasil evaluasi efisiensi teknis untuk penilaian kinerja industri manufaktur di Jawa 
Timur menggunakan metode Data Envelopment Analysis (DEA) ditunjukkan pada Gambar 8 Skor efisiensi teknis berkisar antara 0 hingga 1. Skor 1 menunjukkan bahwa kinerja industri tersebut telah mencapai kondisi yang efisien, sementara itu industri yang beroperasi pada kondisi yang inefisien memiliki skor efisiensi teknis kurang dari 1. Berdasarkan Gambar 8 dapat diketahui bahwa rata-rata skor efisiensi yang dicapai industri manufaktur di Jawa Timur adalah sebesar 0,64 sehingga dapat dikatakan bahwa industri manufaktur di Jawa Timur pada tahun 2007-2015 beroperasi secara inefisien dan berpotensi meningkatkan output sebesar 36 persen lagi agar mencapai kondisi yang efisien.

\section{Hasil Estimasi Efisiensi dan Perubahan Produktivitas Industri Manufaktur di Jawa Timur}

Pengukuran perubahan Total Faktor Produktifitas (Total Factor Productivity Change atau TFPC) dapat didekomposisikan menjadi perubahan efisiensi teknis (Technical Efficiency Change atau TEC), perubahan efisiensi skala (Scale Efficiency Change atau SEC), dan perubahan teknologi (Technological Change atau TC). TEC mengukur tingkat perubahan efisiensi relatif pada periode $\boldsymbol{t}$ dengan efisiensi relatif pada periode $\boldsymbol{t}_{+1 \text {. }}$ TEC juga dapat disebut dengan catching-up effect yang mencerminkan komponen perubahan efisiensi dalam perubahan produktivitas. Komponen TEC dapat didekomposisikan menjadi PEC dan SEC dengan menggunakan asumsi VRS pada kedua periode waktunya ( $T_{V R S}^{t}$ dan $\left.T^{t+1}{ }_{V R S}\right)$. Skor TEC lebih dari 1 (100 persen) jika industri mengalami peningkatan efisiensi (perbaikan kinerja), sedangkan skor TEC yang kurang dari 1 (100 persen) dapat diartikan bahwa industri tersebut mengalami penurunan efisiensi (kinerja yang memburuk), dan skor TEC yang sama dengan 1 menandakan bahwa industri tersebut stagnan. Skor SEC lebih dari 1 (100 persen) jika industri mengalami peningkatan efisiensi skala, sedangkan skor SEC yang kurang dari 1 (100 persen) dapat diartikan bahwa industri tersebut mengalami penurunan efisiensi skala, dan skor SEC yang sama dengan 1 menandakan bahwa industri tersebut memiliki efisiensi skala yang stagnan.

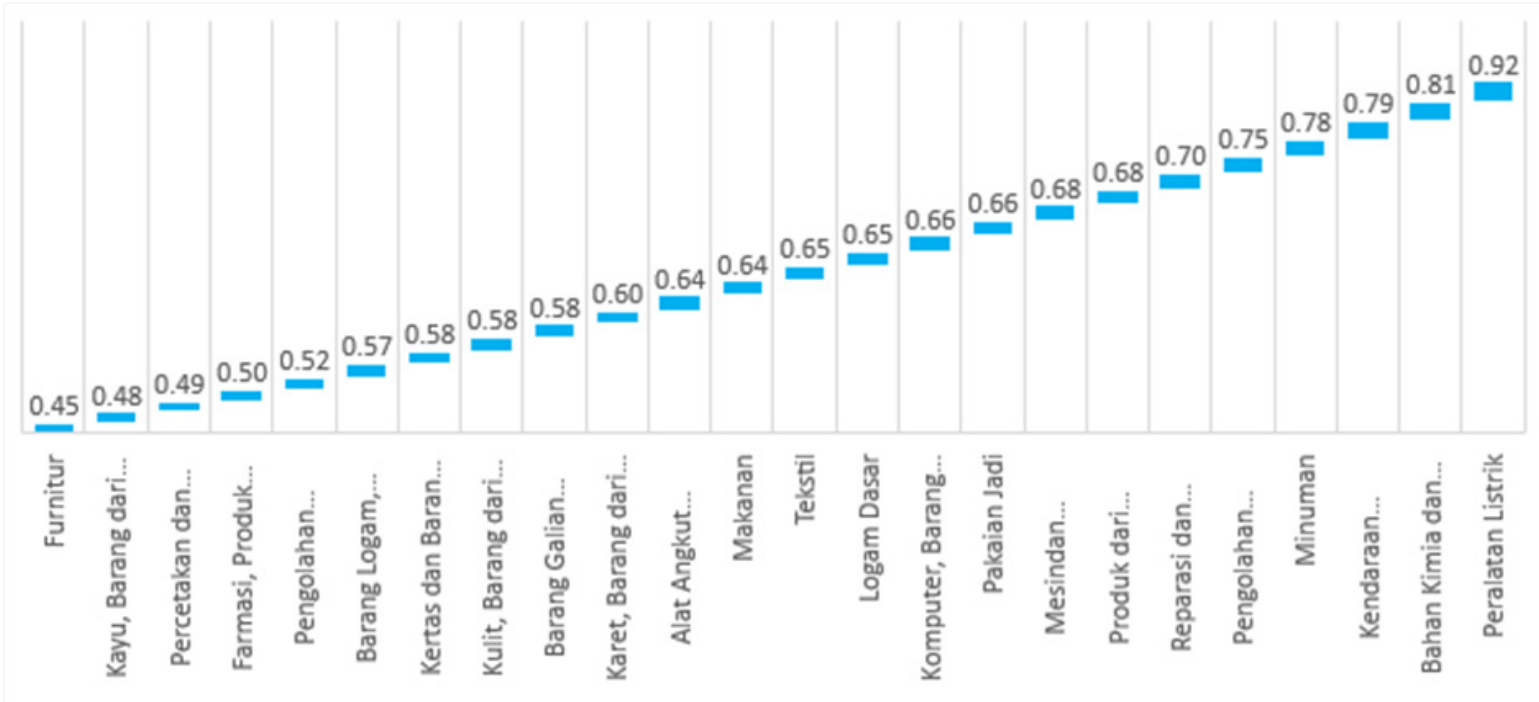

Sumber: Hasil olahan data

\section{Gambar 8: Skor Efisiensi Teknis Industri Manufaktur di Jawa Timur Tahun 2007-2015}

Gambar 8 di atas menunjukkan skor efisiensi teknis manufaktur di Jawa Timur hasil estimasi DEA pada tahun 2007 hingga 2015. Pada rentang tahun 2007 hingga 2015, industri peralatan listrik menjadi industri yang paling mendekati kondisi efisien yaitu dengan perolehan skor efisiensinya sebesar 0,92 atau dapat dikatakan bahwa rata-rata output maksimum yang dapat dihasilkan dari output potensial indsutri mencapai 92 persen dari penggunaan 
input dan teknologi sehingga hanya perlu meningkatkan output potensial sebesar 8 persen untuk mencapai kondisi yang efisien. Skor efisiensi teknis industri manufaktur di Jawa Timur yang terbesar kedua dan ketiga adalah industri bahan kimia dan barang dari bahan kimia dan industri kendaraan bermotor, trailer, dan semi trailer dengan masing-masing perolehan skor efisiensi sebesar 0,81 dan 0,79. Di sisi lain, industri furnitur menjadi industri yang paling tidak efisien pada industri manufaktur di Jawa Timur tahun 2007-2015. Industri furnitur rata-rata output maksimum yang dapat dihasilkan dari output potensial seluruh industri hanya sebesar 4,5 persen dari penggunaan input dan teknologi sehingga perlu meningkatkan output potensial sebesar 95,5 persen untuk mencapai kondisi yang efisien. Industri kayu, barang dari kayu dan gabus (tidak termasuk furnitur) dan barang anyaman dari bambu, rotan dan sejenisnya dan industri percetakan dan reproduksi media rekaman menjadi industri yang memiliki skor efisiensi terendah kedua dan ketiga pada industri manufaktur di Jawa Timur tahun 2007-2015 dengan masing-masing perolehan skor sebesar 0,48 dan 0,49. Berdasarkan Gambar 8 dapat diketahui bahwa sebanyak 42 persen (10 industri) dalam industri manufaktur di Jawa Timur pada jangka waktu tahun 2007-2015 memiliki rata-rata skor efisiensi kurang dari rata-rata yaitu 0,64 , sedangkan sisanya (14 industri) telah mencapai rata-rata skor efisiensi teknis (lebih dari 0,64).

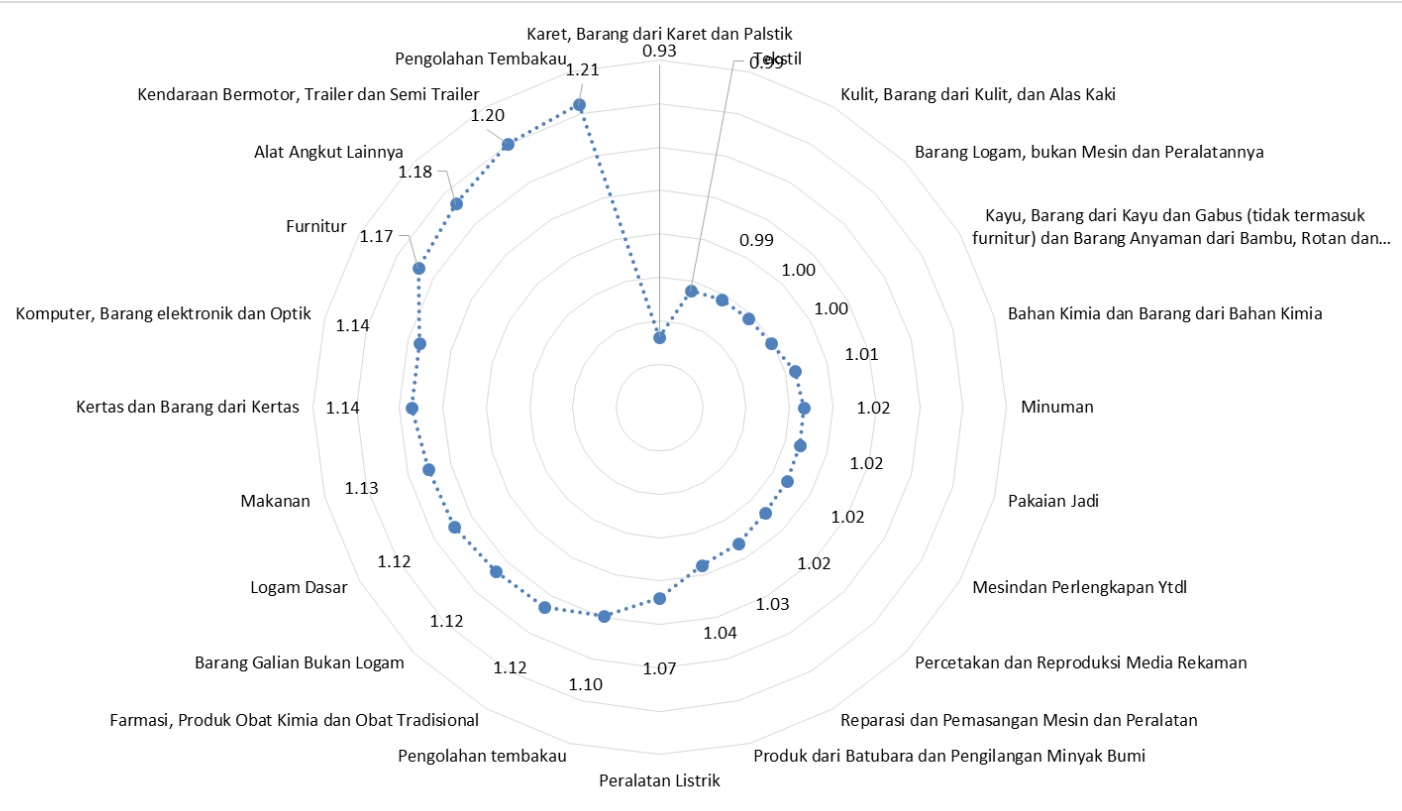

Sumber: Hasil olahan data

\section{Gambar 9: Skor Technical Efficiency Change (TEC) Industri Manufaktur di Jawa Timur Tahun 2007-2015}

Mengacu pada Gambar 9, pada periode tahun 2007-2015 dalam industri manufaktur Jawa Timur sebesar 79 persen (19 industri) yang telah mengalami peningkatan kinerja dengan perolehan skor TEC lebih dari 1. Industri pengolahan tembakau menjadi industri yang memiliki kecenderungan peningkatan kinerja tertinggi pada industri manufaktur di Jawa Timur yaitu sebesar 21 persen setiap tahunnya pada rentang waktu 2007-2015. Di sisi lain, sebesar 12,5 persen ( 3 industri) belum mencapai rata-rata perubahan efisiensi teknis yang meningkat atau dapat dikatakan mengalami kinerja yang memburuk. Ketiga industri yang cenderung mengalami penurunan kinerja pada tahun 2007-2015 adalah industri karet, barang dari karet dan plastik, industri tekstil, industri kulit, barang dari kulit, dan alas dari kulit. Di sisi lain industri 
barang logam, bukan mesin dan peralatannya, dan industri kayu, barang dari kayu, dan gabus cenderung mengalami perubahan efisiensi teknis yang stagnan.

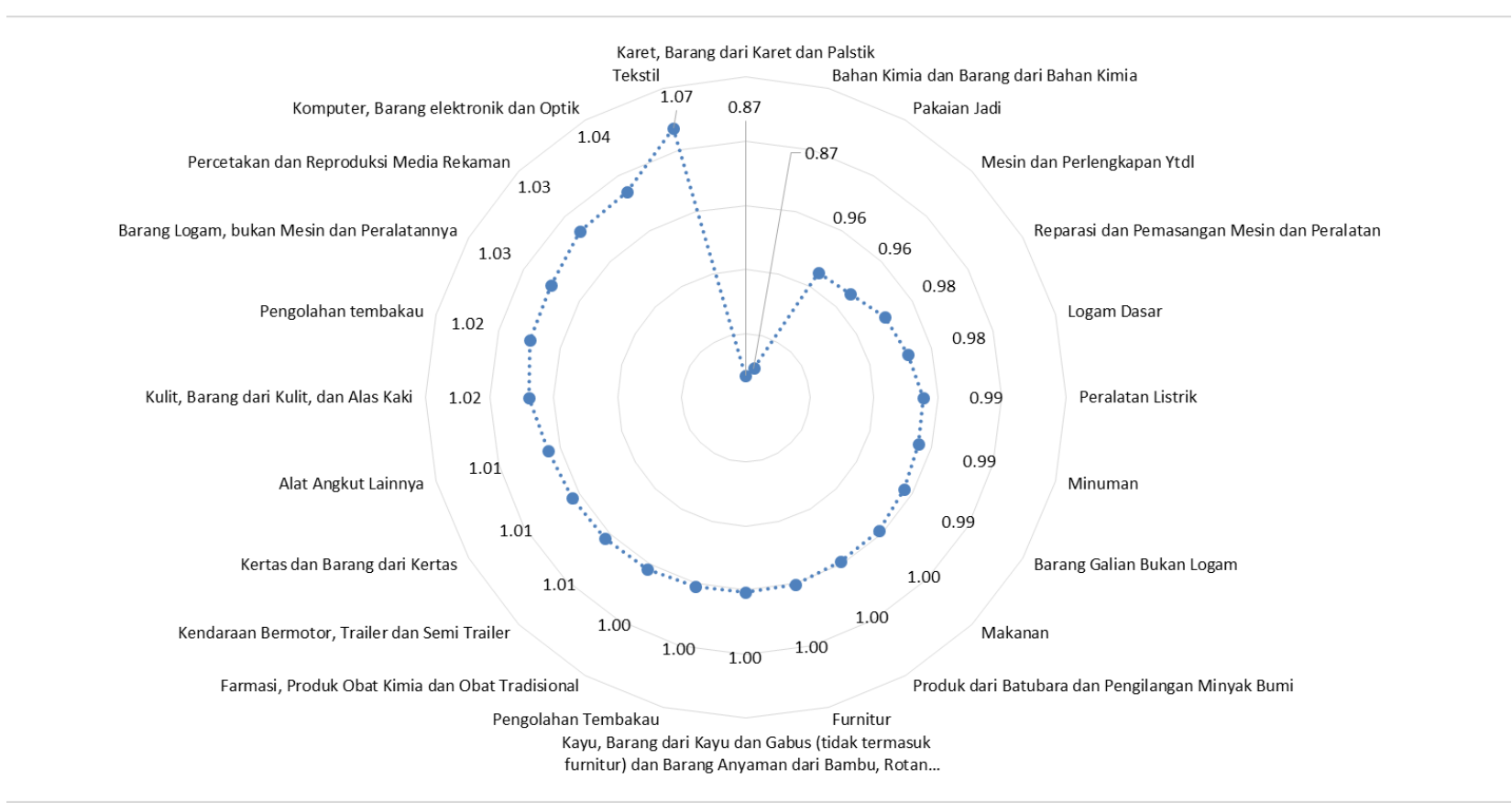

Sumber: Hasil olahan data

\section{Gambar 10: Skor Scale Efficiency Change (SEC) Industri Manufaktur di Jawa Timur Tahun 2007-2015}

Sesuai dengan Gambar 10, pada periode tahun 2007-2015 dalam industri manufaktur di Jawa Timur sebesar 37,5 persen ( 9 industri) yang telah mengalami peningkatan rata-rata efisiensi skala dengan perolehan skor SEC lebih dari 1. Industri tekstil menjadi industri yang memiliki kecenderungan peningkatan efisiensi skala tertinggi pada industri manufaktur di Jawa Timur yaitu dengan peningkatan sebesar 7 persen setiap tahunnya pada rentang waktu 2007-2015. Di sisi lain, juga sebesar 37,5 persen ( 9 industri) yang mengalami penurunan efisiensi skala pada tahun 2007-2015 dengan perolehan skor SEC kurang dari 1. Tercatat juga bahwa 25 persen (6 industri) mengalami perubahan efisiensi teknis yang stagnan.

Kemajuan teknologi (frontier shift change) memungkinkan industri berproduksi menghasilkan ouput lebih banyak dengan kombinasi input tertentu yang tetap atau dengan memproduksi output di tingkat yang sama namun dengan menggunakan kombinasi input yang lebih sedikit. Adanya peningkatan dalam penggunaan teknologi suatu DMU ditandakan oleh skor TC yang lebih dari 1 (technological progress). Di sisi lain, skor TC yang kurang dari 1 mengindikasikan bahwa DMU tersebut mengalami penurunan teknologi (technological regress). Berdasarkan Gambar 11 di atas dapat diketahui bahwa semua industri manufaktur di Jawa Timur pada tahun 2007-2015 cenderung mengalami peningkatan teknologi (technological progress). Rata-rata skor TC sebesar 1,54 yang berarti bahwa peningkatan teknologi pada industri manufaktur di Jawa Timur pada tahun 2007-2015 sebesar 54 persen. Industri reparasi dan pemasangan mesin dan peralatan menjadi industri yang paling tinggi tingkat technological regress-nya. 


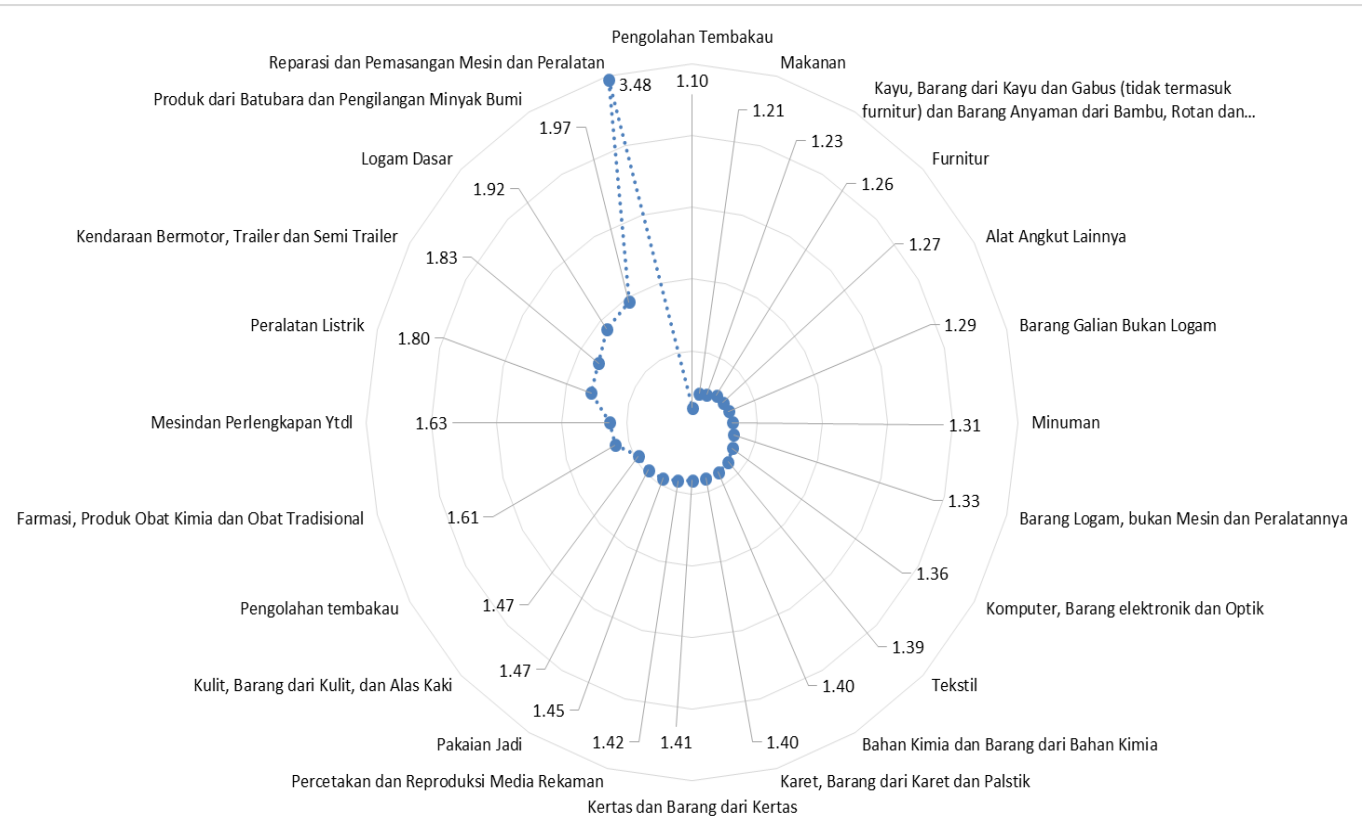

Sumber: Hasil olahan data

Gambar 11: Skor Technological Change (TC) Industri Manufaktur di Jawa Timur Tahun 2007-2015

Industri logam dasar memiliki peningkatan produktivitas tertinggi di industri manufaktur di Jawa Timur dengan peningkatan produktivitas rata-rata sebesar 2,35 kali setiap tahunnya (Gambar 12). Peningkatan teknologi sebesar 92 persen setiap tahunnya pada industri logam dasar menjadi yang paling berkontribusi dalam pencapaian ini. Di sisi lain, peningkatan produktivitas industri minuman menjadi yang paling terendah di antara industri manfaktur lainnya yaitu hanya sebesar 4 persen setiap tahunnya. Keseluruhan industri manufaktur di Jawa Timur tahun 2007-2015 mengalami peningkatan produktivitas rata-rata sebesar 55 persen setiap tahunnya.

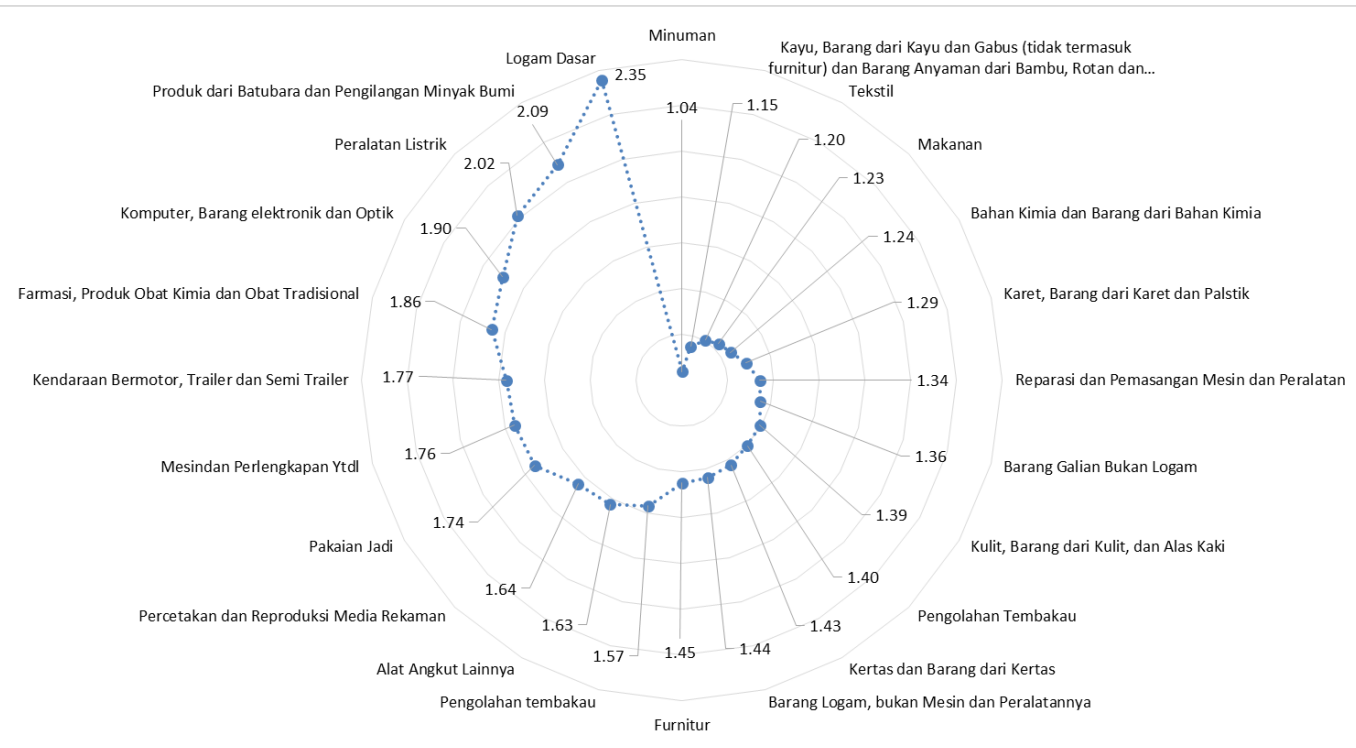

Sumber: Hasil olahan data

Gambar 12: Skor Total Factor Productivity Change (TFPC) Industri Manufaktur di Jawa Timur Tahun 2007-2015 


\section{Pengujian Konvergensi Efisiensi Industri}

Model konvergensi pertama yang dianalisis dalam penelitian ini adalah beta kondisional menggunakan model analisis Sys-GMM. Berdasarkan penelitian terdahulu, hasil pengujian konvergensi beta kondisional lebih akurat dibandingkan dengan beta absolut, karena melibatkan berbagai faktor yang diduga mempengaruhi efisien industri manufaktur, sehingga ketika faktor-faktor tersebut diabaikan maka hasil pengujian menjadi bias.

Tabel 2: Hasil Estimasi GMM

\begin{tabular}{|c|c|c|}
\hline Variabel & Koefisien & P-value \\
\hline L.Efisiensi & 0,5658632 & $0,000 *$ \\
\hline Intensitas Energi & $-0,0003231$ & $0,000 *$ \\
\hline Rasio Modal-Tenaga Kerja & 0.0000000437 & $0,001^{*}$ \\
\hline Intensitas Modal & $-0,0196753$ & $0,001^{*}$ \\
\hline Share Industri & 0,6716609 & $0,000 *$ \\
\hline Konstanta & 0,2642351 & $0,000 *$ \\
\hline$A R(1)$ & - & $0,000 *$ \\
\hline$A R(2)$ & - & $0.576 * *$ \\
\hline Sargan Test & - & $0,887^{* *}$ \\
\hline Hansen Test & - & $0,232 * *$ \\
\hline Hansen GMM & - & $0,344 * *$ \\
\hline Hansen -Diff-GMM & - & $0,196 * *$ \\
\hline Hansen IV & - & $0,456 * *$ \\
\hline Hansen -Diff-IV & - & $0,111 * *$ \\
\hline Prob. F & - & $0,000 *$ \\
\hline
\end{tabular}

Keterangan: $\left.{ }^{*}\right)$ Signifikan pada level $1 \%$

Sumber: Hasil olahan data

Penggunaan analisis GMM memiliki tiga kriteria untuk mendapatkan model yang terbaik. Kriteria pertama yaitu konsisten. Konsistensi hasil estimasi bisa dilihat dari nilai p-value Arellano-Bond for AR(1) yang signifikan dan Arellano-Bond for AR(2) yang tidak signikan. Hasil etimasi GMM pada Tabel 2 menunjukkan bahwa p-value $A R(1)$ dan $A R(2)$ adalah 0,000 dan 0,576, sehingga untuk $A R(1) H O$ ditolak dan $\mathrm{H} 1$ diterima, sedangkan AR(2) HO diterima dan $\mathrm{H} 1$ ditolak, yang artinya hasil estimasi GMM konsisten. Kriteria kedua adalah instrumen yang valid, untuk mengetahui validitas instrumen maka dilakukan uji identifikasi overidentifying dengan menggunakan Sargan test dan Hansen test. Nilai p-value dari Sargan test dan Hansen test yang ditunjukkan dalam Tabel 2 adalah 0,887 dan 0,232, sehingga $\mathrm{HO}$ diterima dan $\mathrm{H} 1$ ditolak, yang artinya model GMM yang digunakan tidak memiliki masalah dengan validitas instrumen. Kriteria model GMM terbaik yang terakhir adalah tidak adanya autokorelasi antar individu, yaitu dengan melakukan pengujian Arellano-Bond for AR(2). Hasil estimasi AR(2) pada penelitian ini memiliki p-value sebesar 0,576 yang artinya $\mathrm{HO}$ diterima. Hipotesis null dalam pengujian tersebut menunjukkan bahwa tidak terdapat autokorelasi antar variabel, sehingga hasil estimasi menjadi tidak bias (valid). Berdasarkan tiga pengujian tersebut maka model GMM yang digunakan dalam penelitian sudah memenuhi tiga kriteria model GMM terbaik.

Pengujian GMM merupakan salah satu metode yang menganalisis model data panel dinamis. Hubungan dinamis dalam pengujian ini ditunjukkan oleh lag efisiensi (variabel endogen) dengan nilai $p$-value sebesar 0,000 yang artinya analisis tahun $t$ signifikan secara statistik dipengaruhi oleh tahun t-1 (periode sebelumnya). Koefisien lag efisiensi juga memiliki nilai positif sebesar 0,8726394 dan signifikan secara statistik yang menunjukkan adanya indikasi 
divergensi beta kondisional pada efisiensi industri manufaktur di Provinsi Jawa Timur. Hasil estimasi GMM (Tabel 2) menunjukkan nilai probabilitas $\mathrm{F}$ sebesar 0,000 yang artinya variabel independen secara simultan signifikan berpengaruh terhadap variabel dependen.

Model analisis kedua yaitu konvergensi sigma yang merupakan salah satu jenis konvergensi yang sudah banyak digunakan pada penelitian sebelumnya seperti Barro dan Martin (1996), Liddle (2012), Hao et al., (2015), dan Mohammadi dan Ram (2017). Konsep dasar konvergensi sigma adalah mengukur dispersi atau sebaran data dari efisiensi industri dalam kurun waktu tertentu. Ukuran dispersi yang digunakan dalam penelitian ini adalah standar deviasi yang akan disajikan dalam bentuk grafik seperti Gambar 13. Hasil pengujian menunjukkan adanya tren standar deviasi yang mengalami penurunan, meskipun pada tahun 2010 dan 2013 mengalami peningkatan yang cukup tajam. Sejak tahun 2007 hingga 2015 standar deviasi dari log efisiensi telah mengalami penurunan sebesar 0,0263 . Adanya penurunan standar deviasi tersebut menandakan bahwa telah terjadi konvergeni sigma pada efisiensi industri manufaktur di Provinsi Jawa Timur tahun 2007 hingga 2015.

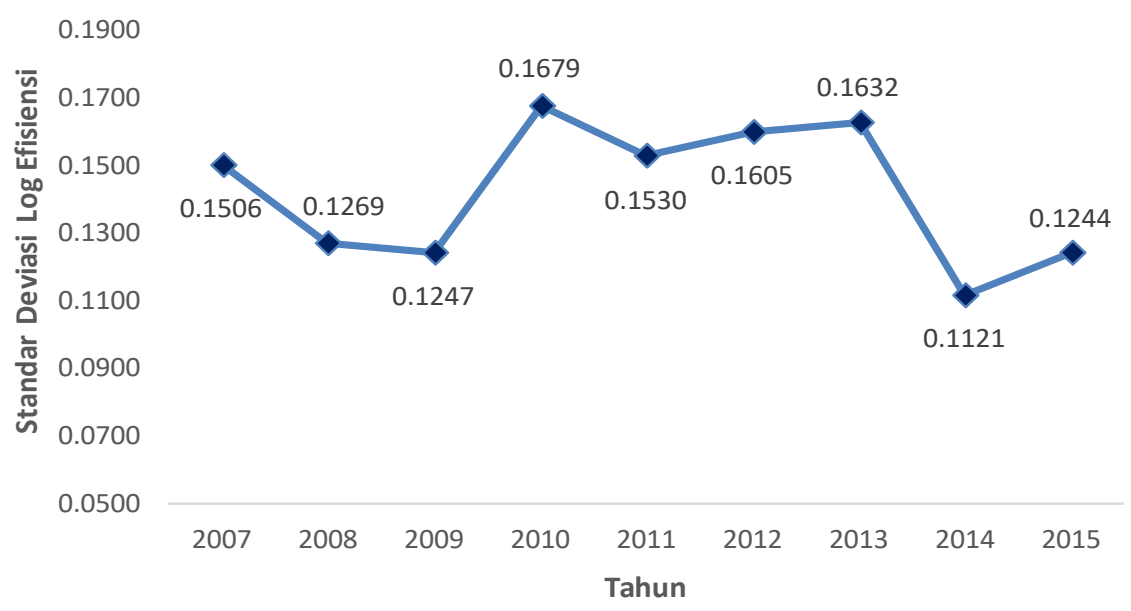

Sumber: Hasil olahan data

\section{Gambar 13: Hasil Pengujian Konvergensi Sigma $(\sigma)$ Efisiensi Industri Manufaktur di Provinsi Jawa Timur pada 2007-2015}

Jika konvergensi beta kondisional dan sigma berfokus pada penurunan dispersi, maka berbeda dengan konvergensi gamma $(\gamma)$ yang berfokus pada mobilitas peringkat (rangking) dari efisiensi masing-maisng sub-sektor industri manufaktur. Peringkat setiap sub-sektor dihitung menggunakan indeks gamma yang memiliki rentang nilai antara 0 dan 1 . Angka indeks 0 menunjukkan bahwa ada mobilitas (perpindahan) peringkat antar sub-sektor atau terjadi konvergensi, sedangkan indeks 1 menunjukkan tidak ada mobilitas peringkat yang artinya ada indikasi divergensi. Sama halnya dengan konvergensi sigma, konvergensi gamma juga disajikan dalam bentuk grafik seperti pada Gambar 14. Hasil pengujian konvergensi gamma menunjukkan bahwa indeks gamma mengalami penurunan sebesar 0,5403 poin. Oleh karena itu dapat disimpulkan bahwa ada indikasi terjadinya konvergensi gamma pada efisiensi industri manufaktur di Provinsi Jawa Timur dalam kurun waktu 2007 hingga 2015. 


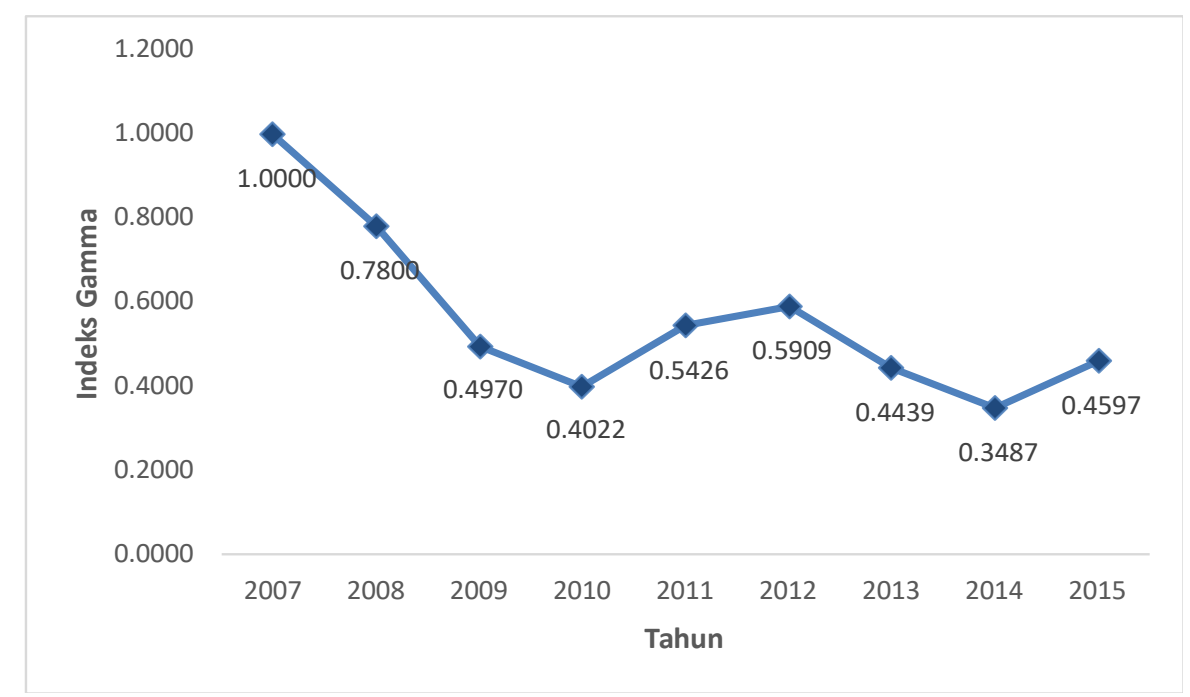

Sumber: Hasil olahan data

\section{Gambar 14: Hasil Pengujian Konvergensi Gamma ( $v$ ) Efisiensi Industri Manufaktur di Provinsi Jawa Timur pada 2007-2015}

Analisis model konvergensi yang terakhir adalah konvergensi stokastik yang berfokus pada stasioneritas data efisiensi industri. Konvergensi stokastik adalah variasi antara efisiensi industri dan rata-rata efisiensi industri untuk semua sub-sektor industri manufaktur harus sesuai atau stasioner. Stasioner adalah suatu kondisi data time series yang jika rata-rata, varian, dan kovarian dari peubah-peubah tersebut seterusnya tidak berubah meskipun terdapat penambahan waktu, dan goncangannya hanya bersifat sementara. Hasil pengujian konvergensi stokastik yang menggunakan Im-Pesaran-Shin (IPS) test pada Tabel 3 menunjukkan bahwa $\mathrm{HO}$ ditolak dan $\mathrm{H} 1$ diterima, karena nilai p-value dari efisiensi adalah sebesar 0,0000 atau kurang dari $1 \%$. Hipotesis null dalam uji IPS menyatakan bahwa data mengandung unit root, sehingga ketika $\mathrm{HO}$ ditolak maka dapat dikatakan bahwa data efisiensi tidak mengandung unit root atau bersifat stasioner. Oleh karena itu, dapat disimpulkan bahwa ada indikasi konvergensi efisiensi industri manufaktur di Provinsi Jawa timur dalam kurun waktu 2007 hingga 2015.

Tabel 3: Hasil Estimasi Im-Pesaran-Shin (IPS)

\begin{tabular}{cc}
\hline Koefisien Efisiensi & p-value Efisiensi \\
\hline$-4,1347$ & $0,0000^{*}$ \\
\hline Sumber: Hasil olahan data &
\end{tabular}

Estimasi dan pengujian secara statistik telah dilakukan pada empat model konvergensi yang dianalisis dalam penelitian ini, yaitu konvergensi beta $(\beta)$ kondisional, konvergensi sigma $(\sigma)$, konvergensi gamma $(\gamma)$, dan konvergensi stokastik. Rangkuman dari hasil estimasi dan pengujian tersebut dapat dilihat pada Tabel 4 Berdasarkan beberapa hasil estimasi dan pengujian tersebut dapat ditarik kesimpulan bahwa ada indikasi terjadinya konvergensi efiaiensi pada sektor industri manufaktur di Provinsi Jawa Timur dalam kurun waktu tahun 2007 hingga 2015. Indikasi terjadinya konvergensi efisiensi menunjukkan bahwa perubahan yang terjadi pada efisiensi industri sudah menuju ke arah yang sama atau sudah menuju garis frontier karena dispersinya sudah mengalami penurunan, sehingga hipotesis mengenai adanya catching-up effect oleh sub-sektor dengan efisiensi yang lebih rendah sudah terjadi. 
Tabel 4: Rangkuman Hasil Pengujian Konvergensi Efisiensi Industri

\begin{tabular}{ll}
\hline \multicolumn{1}{c}{ Model Analisis } & \multicolumn{1}{c}{ Hasil Analisis } \\
\hline $\begin{array}{l}\text { Konvergensi Beta }(\beta) \\
\text { Kondisional }\end{array}$ & $\begin{array}{l}\text { Terindikasi terjadi divergensi } \\
\text { beta }(\beta) \text { kondisional }\end{array}$ \\
\hline Konvergensi Sigma $(\sigma)$ & $\begin{array}{l}\text { Terindikasi terjadi konvergensi } \\
\text { sigma }(\sigma)\end{array}$ \\
\hline Konvergensi Gamma $(\gamma)$ & $\begin{array}{l}\text { Terindikasi terjadi konvergensi } \\
\text { gamma }(\gamma)\end{array}$ \\
\hline & $\begin{array}{l}\text { Terindikasi terjadi konvergensi } \\
\text { stokastik }\end{array}$ \\
\hline
\end{tabular}

Sumber: Hasil olahan data

Satu dari keempat model konvergensi menunjukkan hasil yang berbeda, hal tersebut juga terjadi pada penelitian yang dilakukan oleh Mohammadi dan Ram (2017). Perbedaan hasil analisis bisa berbeda karena keempat model tersebut dianalisis menggunakan metode yang berbeda, sehingga wajar bila ada perbedaan hasil analisis (Mohammadi dan Ram, 2017:408).

\section{Faktor-faktor yang Mempengaruhi Efisiensi Industri Manufaktur di Provinsi Jawa Timur pada 2007-2015}

Berdasarkan hasil estimasi GMM pada tabel 2 semua variabel signifikan berpengaruh terhadap efisiensi industri manufaktur pada level $1 \%$ dengan tanda yang berbeda-beda. Intensitas energi merupakan salah satu variabel signifikan berpengrauh terhadap efisiensi industri di Provinsi Jawa Timur dalam kurun waktu tahun 2007 hingga 2015. Nilai koefisien yang negatif sebesar 0,5659 menunjukkan bahwa ketika variabel intensitas energi mengalami peningkatan satu satuan, maka variabel efisiensi akan menurun sebesar 0,5659 satuan. Variabel intensitas energi menggambarkan besarnya energi yang dibutuhkan untuk memproduksi satu unit output, sehingga semakin tinggi intensitas ini maka penggunaan energi semakin tidak efisien, karena untuk memproduksi satu unit output membutuhkan energi yang lebih besar. Oleh karena itu intensitas energi yang tinggi akan berdampak negatif terhadap efisiensi industri manufaktur. Energi merupakan salah satu input yang berperan penting dalam proses produksi output pada industri manufaktur yang banyak menggunakan mesin yang digerakkan oleh energi, sehingga pasokan energi harus terus dijaga dalam harga yang stabil agar industri bisa melakukan produksi secara efisien.

Variabel kedua yang signifikan berpengaruh terhadap efisiensi industri manufaktur di Provinsi Jawa timur adalah rasio modal-tenaga kerja. Nilai koefisien rasio modal-tenaga kerja positif sebesar 4,37e-08 menunjukkan bahwa ketika rasio modal-tenaga kerja meningkat satu satuan maka efisiensi akan meningkat sebesar 4,37e-08 satuan. Variabel rasio modal-tenaga kerja menunjukkan besarnya modal yang digunakan oleh satu pekerja.

Intensitas Modal merupakan salah satu variabel yang signifikan berpengaruh terhadap efisiensi industri manufaktur di Provinsi Jawa Timur dengan nilai negatif. Nilai koefisien intensitas modal negatif sebesar 0,0196 menunjukkan bahwa ketika intensitas modal meningkat satu satuan maka efisiensi industri akan mengalami penurunan sebesar 0,0196. Intensitas modal menggambarkan besarnya modal yang digunakan untuk memproduksi satu unit output, sehingga semakin tinggi intensitas modal maka proses produksi menjadi tidak efisien karena untuk memproduksi satu unit output memerlukan modal yang lebih tinggi.

Share industri merupakan variabel terakhir yang signifikan berpengaruh terhadap efisiensi industri manufaktur di Provinsi Jawa Timur dengan tanda positif. Nilai koefisien yang positif sebesar 0,6717 menunjukkan bahwa ketika share industri meningkat satu satuan maka 
efisiensi industri mengalami penigkatan sebesar 0,6717 satuan. Hal ini dikarenakan semakin tinggi output yang dihasilkan oleh suatu industri dengan input dalam jumlah yang sama atau lebih sedikit menunjukkan bahwa efisiensi produksi sudah tercapai.

\section{Kesimpulan}

Berdasarkan latar belakang, rumusan masalah, dan pembahasan yang telah dipaparkan sebelumnya, maka penelitian ini dapat disimpulkan sebagai berikut:

1. Skor efisiensi teknis yang dapat dicapai industri manufaktur di Jawa Timur dalam rentang waktu 2007-2015 adalah sebesar 0,64 yang berarti bahwa industri ini masih beroperasi secara inefisien dan berpotensi meningkatkan outputnya sebesar 36 persen lagi agar mencapai kondisi efisien. Keseluruhan industri manufaktur di Jawa Timur tahun 20072015 mengalami peningkatan produktivitas rata-rata sebesar 55 persen setiap tahunnya. Industri logam dasar memiliki peningkatan produktivitas tertinggi di industri manufaktur di Jawa Timur dengan peningkatan produktivitas rata-rata sebesar 2,35 kali setiap tahunnya.

2. Hasil pengujian konvergensi sigma $(\sigma)$, konvergensi gamma $(\nu)$, dan konvergensi stokastik menunjukkan adanya indikasi konvergensi efisiensi industri, sedangkan konvergensi beta $(\beta)$ kondisional mengindikasi adanya divergensi efisiensi industri. Oleh karena itu, dapat disimpulkan bahwa ada indikasi efisiensi industri manufaktur di Provinsi Jawa Timur dalam kurun waktu 2007-2015.

3. Terdapat empat variabel yang signifikan berpengaruh terhadap efisiensi industri manufaktur di Provinsi Jawa Timur dalam kurun waktu 2007-2015. Variabel intensitas energi dan intensitas modal signifikan berpengaruh negatif (menurunkan) terhadap efisiensi industri, sedangkan variabel rasio modal-tenaga kerja positif (meningkatkan) terhadap efisiensi industri.

\section{Daftar Pustaka}

Abramovitz, M. (1986). Catching Up, Forgoing Ahead, and Falling Behind. Journal of Economic History, 46(2), 385-406.

Badan Pusat Statistik. (2009). Klasifikasi Baku Lapangan Usaha indonesia. Cetakan III. Jakarta: Badan Pusat Statistik.

Badan Pusat Statistik. (2012). Indikator Ekonomi Desember 2012. Jakarta: Badan Pusat Statistik.

Badan Pusat Statistik. (2012). OECD Energy Intensity: Measures, Trends, and convergence. Energy Efficiency, 5(4), 583-597.

Badan Pusat Statistik. (2015). Indikator Ekonomi Desember 2015. Jakarta: Badan Pusat Statistik.

Badan Pusat Statistik. (2015). Klasifikasi Baku Lapangan Usaha Indonesia 2015. Jakarta: Badan Pusat Statistik.

Badan Pusat Statistik. (2016). Indikator Ekonomi Mei 2016. Jakarta: Badan Pusat Statistik.

Badan Pusat Statistik. (2017). Conditional convergence in Australia's energy consumption at the sector level. Energy Economics, 62, 396-403.

Badan Pusat Statistik. (2017). Convergence in energy consumption per capita across the US states, 1970-2013: An exploration through selected parametric and non-parametric methods. Energy Economics, 62, 404-410. 
Badan Pusat Statistik Provinsi Jawa Timur. (2018). Provinsi Jawa Timur dalam Angka 2018. Surabaya: Badan Pusat Stastistik Provinsi Jawa Timur.

Balk, B. M. (2001). Scale Efficiency and Productivity Change. Journal of Productivity Analysis, 15(1), 159-183.

Barro, R. J., \& Martin, X. S. (1996). The Classical Approach to Convergence Analysis. The Economic Journal, 106(437), 1019-1036.

Coelli, T. J., Rao, D. S., Donnell, C. J., \& Battese, G. E. (2005). An Introduction to Efficiency and Productivity Analysis. Queensland: Springer Science \& Business Media.

Diskaya, F., Emir, S., \& Orhan, N. (2011). Measuring the Technical Efficiency of Telecommunication Sector within Global Crisis: Comparison of G8 Countries and Turkey. Procedia Social and Behavioral Sciences, 24(1), 206-218.

Farrell, M. J. (1957). The Measurement of Productive Efficiency. Journal of the Royal Statistical Society, 120(3), 253-290.

Flokou, Angeliki, Aletras, V., \& Niakas, D. (2017). A Window-DEA Based Efficiency Evaluation of the Public Hospital Sector in Greece during the 5 Year Economic Crisis. PLOS ONE, 1-26.

Hao, Y., Shuo, W., \& Zhang, Z.-Y. (2015). Examine the convergence in Per Capita Energy Consumption in China with Breakpoints. Energy Procedia Vol. 75 , 2617-2625.

Khayyat, N. T. (2015). Energy Demand in Industry: What Factors Are Important? New York: Springer Science \& Business Media Dordrecht.

Liddle, B. (2012). Revisiting World Energy Intensity Convergence for Regional Differences. Applied Energy, 87, 3218-3225.

Lubis, R. R. (2014). Analisis Efisiensi Teknis, Alokatif dan Ekonomi Produksi Nanas di Kabupaten Subang, Provinsi Jawa Barat. Skripsi S1.

Mohammadi, H., \& Ram, R. (2012). Cross-country convergence in energy and electricity consumption, 1971-2007. Energy Economics, 34, 1882-1887.

Nicholson, W., \& Snyder, C. (2010). Microeconomic Theory Basic Principle and Extensions. USA: Thomson, South-Western.

Paredes, M. (2015, December 29). Inputs and Production Function. Retrieved from cupdf.com.

Porcelli, F. (2009). Measurement of Technical Efficiency: A-brief Survey on Parametric and Non-Parametric Techniques.

Rusydiana, A. S. (2013). Data Envelopment Analysis, CRS dan VRS. Retrieved from DEA Center.

Tangen, S. (2002). Understanding the Concept of Productivity. Proceeding of the 7th Asia Pacific Industrial Engineering and Management Systems Conference (AIPEMS2000), Taipei.

Valdés, B. (2003). An Application of Convergence Theory to Japan's Post-WWII “Economic Miracle". Journal of Economic Education, 34(1), 61-81.

Vincova, I. K. (2005). Using DEA Models to Measure Efficiency. BIATEC, 8(1), 24-28.

Wajdi, M. F. (2010). Pengukuran Kinerja dalam Industri Kecil. Universitas Muhammadiyah Surakarta Online Journal, 101-111. 


\section{Lampiran}

\section{Hasil Estimsi Sys-GMM}

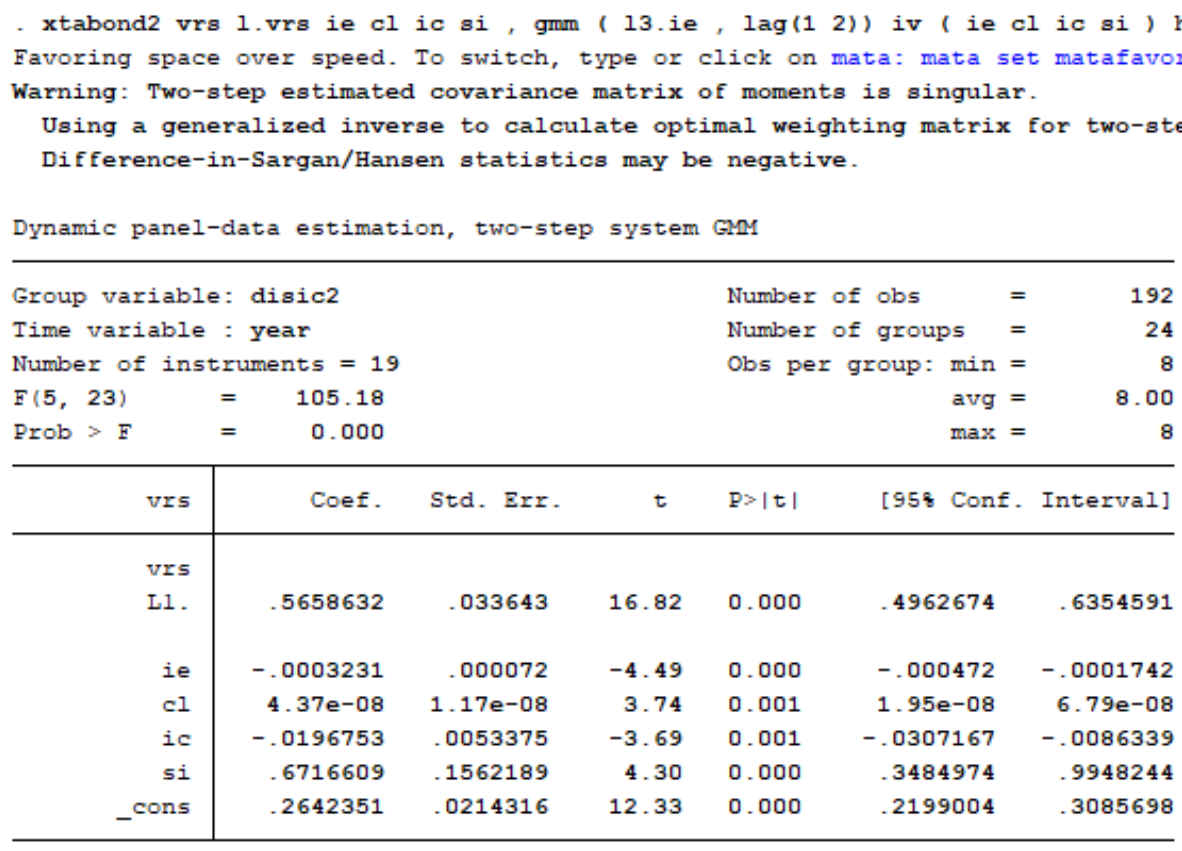

Warning: Uncorrected two-step standard errors are unreliable.

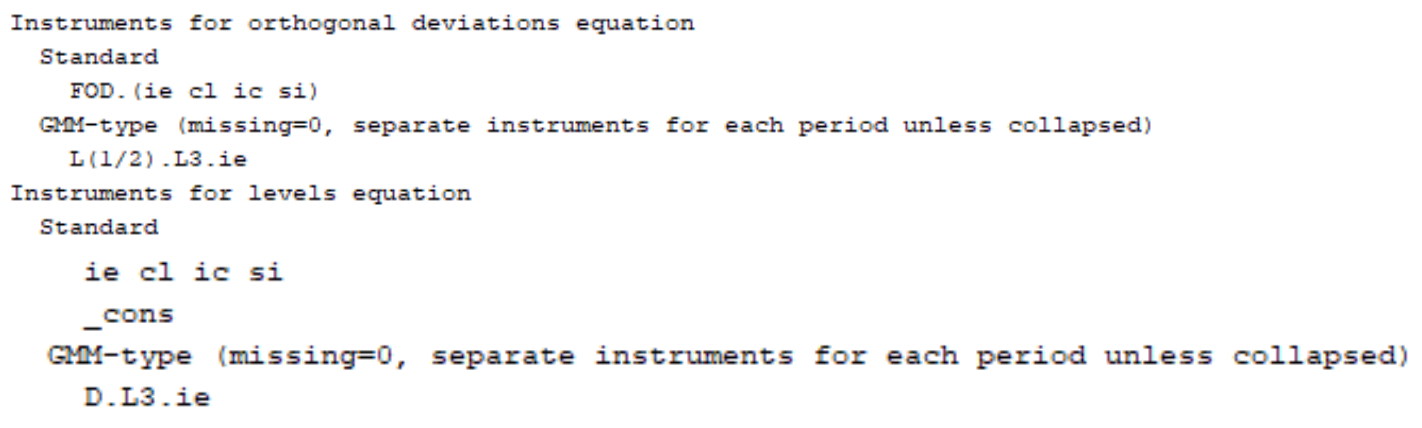

Arellano-Bond test for AR(1) in first differences: $z=-3.59$ Pr $>z=0.000$ Arellano-Bond test for AR(2) in first differences: $z=-0.56$ Pr $>z=0.576$

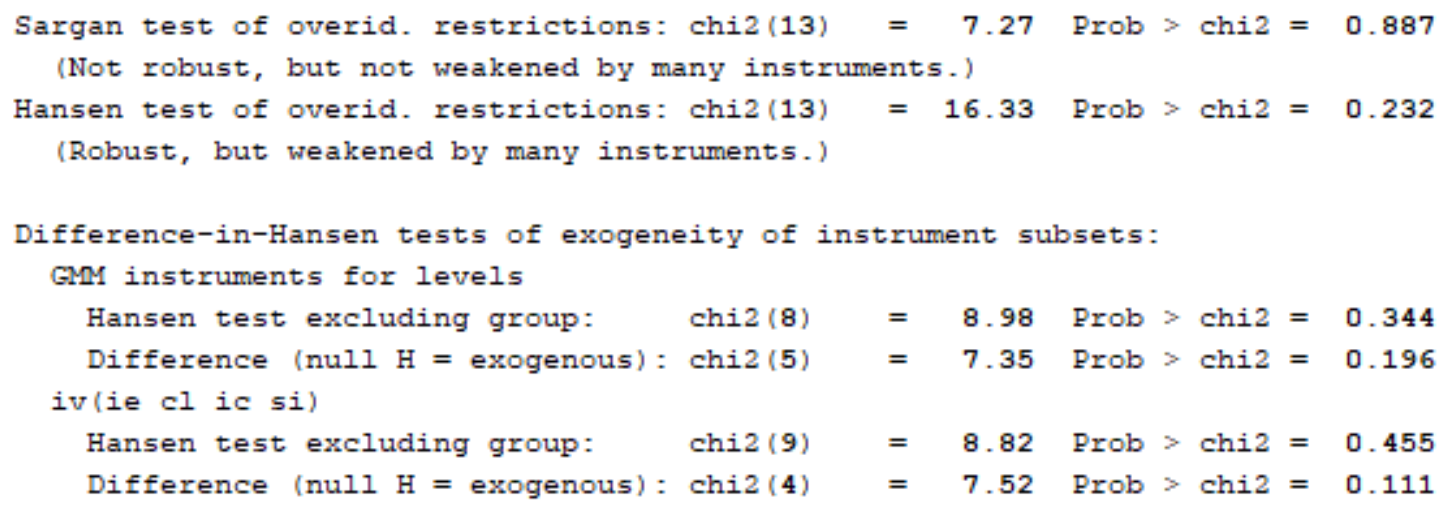




\section{Hasil Estimasi Im-Pesaran-Shin (IPS)}

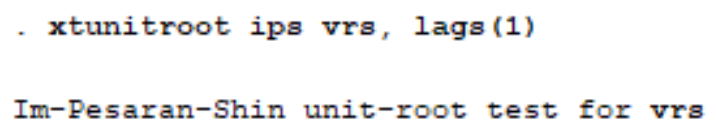

\begin{tabular}{lll}
\hline & Statistic & p-value \\
\hline W-t-bar & -4.1347 & 0.0000
\end{tabular}

